In cooperation with the Sacramento Regional County Sanitation District

\title{
Dissolved Pesticide Concentrations in the Lower Sacramento River and Its Source Waters, California, 2016
}

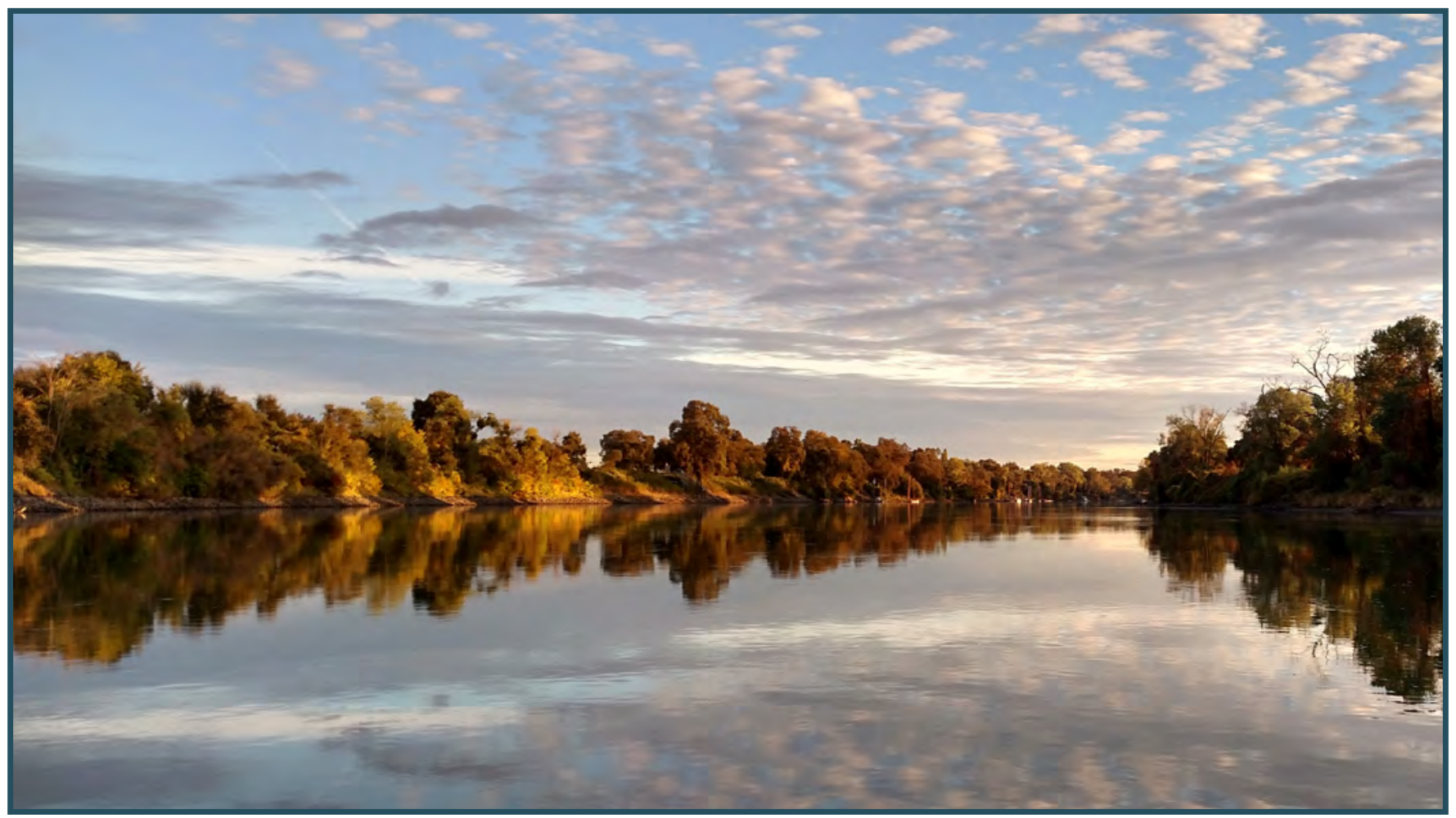

Open-File Report 2018-1153 
Cover images: Fall scenes of the Sacramento River, 2016.

(Photographs by Lisa Thompson, Sacramento Regional County Sanitation District, used with permission) 


\section{Dissolved Pesticide Concentrations in the Lower Sacramento River and Its Source Waters, California, 2016}

By Sean M. Stout, James L. Orlando, Megan McWayne, Corey Sanders, and Michelle Hladik

In cooperation with the Sacramento Regional County Sanitation District

Open-File Report 2018-1153 


\title{
U.S. Department of the Interior \\ RYAN K. ZINKE, Secretary
}

\author{
U.S. Geological Survey \\ James F. Reilly II, Director
}

U.S. Geological Survey, Reston, Virginia: 2018

For more information on the USGS - the Federal source for science about the Earth, its natural and living resources, natural hazards, and the environment-visit https://www.usgs.gov or call 1-888-ASK-USGS.

For an overview of USGS information products, including maps, imagery, and publications,

visit https://store.usgs.gov.

Any use of trade, firm, or product names is for descriptive purposes only and does not imply endorsement by the U.S. Government.

Although this information product, for the most part, is in the public domain, it also may contain copyrighted materials as noted in the text. Permission to reproduce copyrighted items must be secured from the copyright owner.

Suggested citation:

Stout, S.M., Orlando, J.L., McWayne, M., Sanders, C., and Hladik, M., 2018, Dissolved pesticide concentrations in the lower Sacramento River and its source waters, California, 2016: U.S. Geological Survey Open-File Report 2018-1153, 24 p., https://doi.org/10.3133/ofr20181153. 


\section{Contents}

Abstract

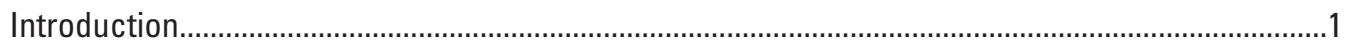

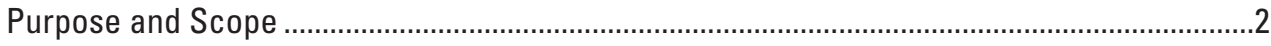

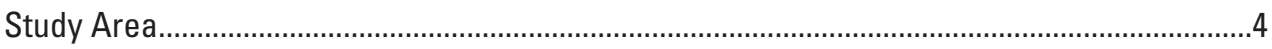

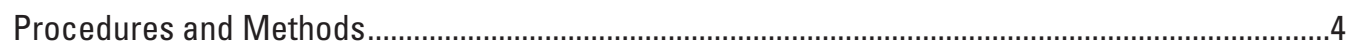

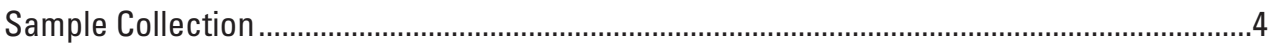

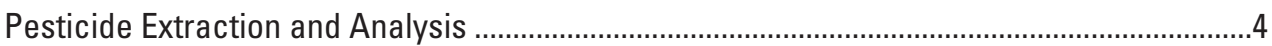

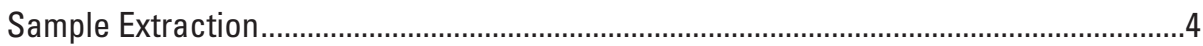

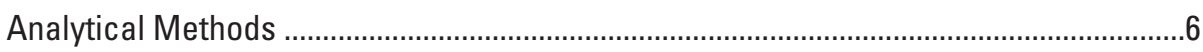

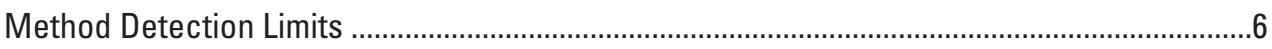

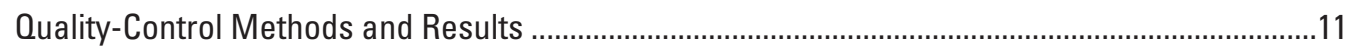

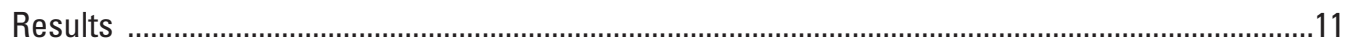

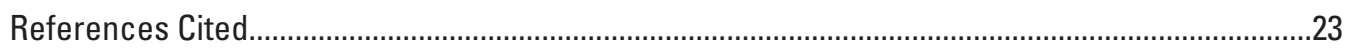

\section{Figures}

1. Map showing locations of indicator and integrator sampling sites in the lower Sacramento River watershed, California..............................................................................

2. Graph showing the number of pesticides detected at sites in the Sacramento River watershed, California, during May and October 2016 ..................................................12

3. Graph showing pesticide detection frequencies in 16 samples from sites in the Sacramento River watershed, California, during May 2016 ............................................20

4. Boxplots summarizing frequency distribution of concentrations of the most frequently detected pesticides at sites in the Sacramento River watershed, California, during May 2016.

5. Graph showing pesticide detection frequencies in 16 samples from sites in the Sacramento River watershed, California, during October 2016.

6. Boxplots summarizing frequency distribution of concentrations of the most frequently detected pesticides at sites in the Sacramento River watershed, California, during October 2016.

\section{Tables}

1. Surface-water sampling sites in the Sacramento River watershed, California

2. Water-quality parameters measured in samples collected at surface-water sites in the Sacramento River watershed, California, May and October 2016.

3. Method detection limits for dissolved pesticides in surface water and on suspended sediments measured by the U.S. Geological Survey Organic Chemistry Research Laboratory.

4. Pesticide concentrations in surface-water samples collected in the Sacramento River watershed, California, May and October 2016.

5. Detection frequencies and maximum concentrations for selected pesticides in surface-water samples collected at sites in the Sacramento River watershed, California, May and October 2016.

6. Pesticide concentrations in suspended sediment filtered from surface-water samples collected at sites in the Sacramento River watershed, California, May and October 2016 


\section{Conversion Factors}

International System of Units to U.S. customary units

\begin{tabular}{|c|c|c|}
\hline Multiply & By & To obtain \\
\hline \multicolumn{3}{|c|}{ Length } \\
\hline millimeter (mm) & 0.03937 & inch (in.) \\
\hline micrometer $(\mu \mathrm{m})$ & $25,400.0$ & inch (in.) \\
\hline meter $(\mathrm{m})$ & 3.281 & foot $(\mathrm{ft})$ \\
\hline \multicolumn{3}{|c|}{ Area } \\
\hline square kilometer $\left(\mathrm{km}^{2}\right)$ & 0.3861 & square mile $\left(\mathrm{mi}^{2}\right)$ \\
\hline \multicolumn{3}{|c|}{ Volume } \\
\hline microliter $(\mu \mathrm{L})$ & $29,573.5$ & ounce, fluid (fl. oz) \\
\hline milliliter (mL) & 29.5735 & ounce, fluid (fl. oz) \\
\hline liter $(\mathrm{L})$ & 33.81402 & ounce, fluid (fl. oz) \\
\hline cubic meter $\left(\mathrm{m}^{3}\right)$ & 35.31467 & cubic feet $\left(\mathrm{ft}^{3}\right)$ \\
\hline \multicolumn{3}{|c|}{ Flow rate } \\
\hline milliliter per minute $(\mathrm{mL} / \mathrm{min})$ & 0.033814 & ounce, fluid per minute (fl. oz/min) \\
\hline \multicolumn{3}{|c|}{ Mass } \\
\hline milligram (mg) & $28,349.5$ & ounce, avoirdupois (oz) \\
\hline
\end{tabular}

Temperature in degrees Celsius $\left({ }^{\circ} \mathrm{C}\right)$ may be converted to degrees Fahrenheit $\left({ }^{\circ} \mathrm{F}\right)$ as

$$
{ }^{\circ} \mathrm{F}=\left(1.8 \times{ }^{\circ} \mathrm{C}\right)+32 .
$$

\section{Datums}

Vertical coordinate information is referenced to the North American Vertical Datum of 1988 (NAVD 88).

Horizontal coordinate information is referenced to the North American Datum of 1983 (NAD 83). Altitude, as used in this report, refers to distance above the vertical datum.

\section{Supplemental Information}

Specific conductance is given in microsiemens per centimeter at 25 degrees Celsius $(\mu \mathrm{S} / \mathrm{cm}$ at $\left.25^{\circ} \mathrm{C}\right)$.

Concentrations of chemical constituents in water are given in either milligrams per liter (mg/L) or micrograms per liter ( $\mu \mathrm{g} / \mathrm{L})$, or nanograms per liter $(\mathrm{ng} / \mathrm{L})$. 


\section{Abbreviations}

$\begin{array}{ll}\text { 3,4-DCA } & \text { 3,4-Dichloroaniline } \\ \text { DCM } & \text { dichloromethane } \\ \text { DCPMU } & \text { N-3,4-dichlorophenyl-N-methyl-urea } \\ \text { EtOAC } & \text { ethyl acetate } \\ \text { GC/MS } & \text { gas chromatography with mass spectrometry } \\ \text { LC/MS/MS } & \text { liquid chromatography with tandem mass spectrometry } \\ \text { OCRL } & \text { Organic Chemistry Research Laboratory } \\ \text { Regional San } & \text { Sacramento Regional County Sanitation District } \\ \text { SPE } & \text { solid phase extraction } \\ \text { USGS } & \text { U.S. Geological Survey }\end{array}$




\title{
Dissolved Pesticide Concentrations in the Lower Sacramento River and Its Source Waters, California, 2016
}

\author{
By Sean M. Stout, James L. Orlando, Megan McWayne, Corey Sanders, and Michelle Hladik
}

\section{Abstract}

As part of a collaborative study designed to better understand water-quality conditions in the Sacramento River, surface-water samples were collected from the lower Sacramento River and five of its tributaries and then analyzed by the U.S. Geological Survey for a suite of 162 current-use pesticides and pesticide degradates. Samples were collected in May and October 2016 at 16 sites on the Sacramento River and its tributaries. Samples were analyzed for pesticide concentrations by using gas chromatography with mass spectrometry and liquid chromatography with tandem mass spectrometry laboratory methods.

A total of 27 pesticides and pesticide degradates were detected in the water samples collected during the study (12 herbicides, 9 insecticides, 5 fungicides, and 1 synergist). Two herbicides were detected in the suspended sediments filtered from the water samples. Pesticides were detected in 100 percent of the water samples, and mixtures of two or more pesticides were detected at all sites and in all but four samples. The pesticides detected most frequently in the May and October sampling periods were the herbicides hexazinone (detected in 88 percent of the water samples), and diuron (84 percent), and the fungicide azoxystrobin (84 percent). Pesticide concentrations ranged from below the method detection limits to 576 nanograms per liter (clomazone). All pesticides were detected at concentration levels lower than the U.S. Environmental Protection Agency's aquatic life benchmarks (U.S. Environmental Protection Agency, 2017).

During the May sampling period, the fungicides boscalid and azoxystrobin (both 94 percent); the herbicides clomazone, diuron, and hexazinone (all 94 percent); thiobencarb (88 percent); and metolachlor (81 percent) were the most frequently detected compounds. During the October sampling period, the herbicides hexazinone (81 percent) and diuron (75 percent) and the herbicide degradates 3,4-dichloroaniline (75 percent) and N-3,4-dichlorophenyl-N-methyl-urea (50 percent), along with the fungicide azoxystrobin (75 percent) and the insecticide methoxyfenozide (63 percent), were the most frequently detected compounds.

\section{Introduction}

The Sacramento River is the largest in California with an average annual discharge of over 760 million cubic meters. It supplies nearly two-thirds of the annual freshwater to the Sacramento-San Joaquin Delta (hereinafter Delta; California Department of Water Resources, 1993, 1994). The Sacramento River and the Delta are areas of critical habitat for numerous species of concern, including Chinook salmon (Sommer and Mejia, 2013), which are present in the Sacramento River year-round. The recent simultaneous decline in abundance of several pelagic fish species in the Delta has become known as the pelagic organism decline (POD; Sommer and others, 2007). These species and many others rely, in part, on the river's primary producers to support their food chain. Important changes in the pelagic food web have been documented in the Delta during the last two decades, indicating a decline in primary productivity. Physical processes, including water residence times and turbidity, nutrient availability, including anthropogenic loading from effluent (Dugdale and others, 2012; Parker and others, 2012); the presence of contaminants, and predation from invasive clams (Winder and Jassby, 2011; Cloern and Jassby, 2012; Kimmerer, and others, 2012) have all been examined as potential mechanisms affecting primary production. Dissolved anthropogenic contaminants such as current-use pesticides could also have a negative effect on primary producers.

Pesticides, including herbicides, insecticides, and fungicides associated with agricultural and urban runoff, have been detected in the Delta throughout the year and the types and concentrations of these pesticides vary based largely on their use in the Sacramento River watershed (Dileanis and others, 2002; Kratzer and others, 2002; Orlando and Kuivila, 2005; Weston and Lydy, 2010; Orlando and others, 2013; Orlando and others, 2014). Previous studies have shown that environmental levels of herbicides can inhibit phytoplankton growth (Peterson and others, 1994; Ricart and others, 2009). The herbicide diuron, when combined with other herbicides, has been shown to have additive toxic effects (Magnusson and others, 2010), and in mixtures with its degradates, diuron has been shown to act synergistically to inhibit phytoplankton growth (Gatidou and Thomaidis, 2007). 
In addition to herbicides, many insecticides from urban and agricultural sources enter the Sacramento River and either dissolve in the water column or sorb onto particulate matter. Pyrethroids, which are replacing organophosphate insecticides on the market, target invertebrates and could pose a threat to non-target benthic species. Pyrethroids are hydrophobic (Laskowski, 2002), tend to be detected in suspended and bed sediments (Hladik and others, 2009), and are known to be highly toxic to aquatic organisms (Hill, 1989).

To better understand the water-quality conditions in the Sacramento River, the Sacramento Regional County Sanitation District (Regional San) investigated the occurrence of a variety of constituents, including nutrients and pesticides in the Sacramento River. As part of this investigation, the U.S. Geological Survey (USGS) characterized the occurrence and concentrations of current-use pesticides and pesticide degradates in the lower Sacramento River and its source waters during the spring and fall of 2016. Surfacewater samples for pesticide analysis were collected over 5-day periods in May and October 2016 at 16 sites on the Sacramento River and its tributaries (table 1). These sites include pesticide input from catchments representative of various land uses in the lower Sacramento River watershed (fig. 1). Sampled locations can be classified as either "indicator" sites, at locations targeting specific environmental influences (such as agricultural runoff), or as sites considered representative "integrators," characterized by more complex environmental inputs (Gilliom and others, 1995; Domagalski and others, 1998; Panshin and others, 1998). The indicator sites in this study included three agricultural drains and two larger rivers, the Feather and American, all of which are tributary to the Sacramento River. The larger tributaries are integrators of their own watersheds and receive much of their water from areas upstream of agricultural and urban inputs; however, because only one node was sampled on each of these tributaries, they are classified as indicator sites with respect to the Sacramento River.

\section{Purpose and Scope}

This report describes the methods and procedures used in measuring dissolved pesticide concentrations in filtered water samples and associated suspended sediments collected from 16 sites in May and October 2016. Results are presented for a suite of 162 current-use pesticides and pesticide degradates in surface water.

Table 1. Surface-water sampling sites in the Sacramento River watershed, California.

[NWIS, National Water Information System; USGS, U.S. Geological Survey]

\begin{tabular}{lcccc}
\hline \multicolumn{1}{c}{ USGS station name } & $\begin{array}{c}\text { USGS NWIS } \\
\text { station number }\end{array}$ & Latitude $^{1}$ & Longtitude $^{1}$ & Site type $^{-127}$ \\
\hline SACRAMENTO R A R MILE 94.6 NR ROBBINS CA & 385137121440101 & 38.86027 & -121.73368 & Integrator \\
COLUSA BASIN DRAINAGE CANAL A KNIGHTS LANDING CA & 384804121432401 & 38.80108 & -121.72325 & Indicator \\
SACRAMENTO R A R MILE 86.2 NR KNIGHTS LANDING CA & 384623121411401 & 38.77300 & -121.68728 & Integrator \\
SACRAMENTO SLOUGH NR VERONA CA & 384649121381101 & 38.78018 & -121.63746 & Indicator \\
FEATHER R A R MILE 0.4 MI A VERONA CA & 384726121373901 & 38.79058 & -121.62765 & Indicator \\
NATOMAS CROSS CANAL A VERONA CA & 384649121361501 & 38.78028 & -121.60412 & Indicator \\
SACRAMENTO R A VERONA CA & 11425500 & 38.77435 & -121.59829 & Integrator \\
SACRAMENTO R A R MILE 69.5 NR BRYTE CA & 383944121363901 & 38.66222 & -121.61072 & Integrator \\
SACRAMENTO R A R MILE 62.8 A BRYTE CA & 383600121330301 & 38.60008 & -121.55092 & Integrator \\
AMERICAN R 1 MI AB MOUTH CA & 383609121293200 & 38.60240 & -121.49329 & Indicator \\
SACRAMENTO R A R MILE 55.8 NR SACRAMENTO CA & 383225121304601 & 38.54040 & -121.51288 & Integrator \\
SACRAMENTO R A R MILE 46.4 A FREEPORT CA & 382740121301201 & 38.46112 & -121.50347 & Integrator \\
SACRAMENTO R A R MILE 44.0 CA & 382605121310401 & 38.43463 & -121.51884 & Integrator \\
SACRAMENTO R A HOOD CA & 382205121311300 & 38.36797 & -121.52134 & Integrator \\
SACRAMENTO R A R MILE 30.5 NR VORDEN CA & 381703121331101 & 38.28423 & -121.55307 & Integrator \\
SACRAMENTO R A R MILE 19.0 NR ISLETON CA & 381038121352501 & 38.17715 & -121.59023 & Integrator \\
\hline
\end{tabular}

${ }^{1}$ All locations reference the North American Datum of 1983. 


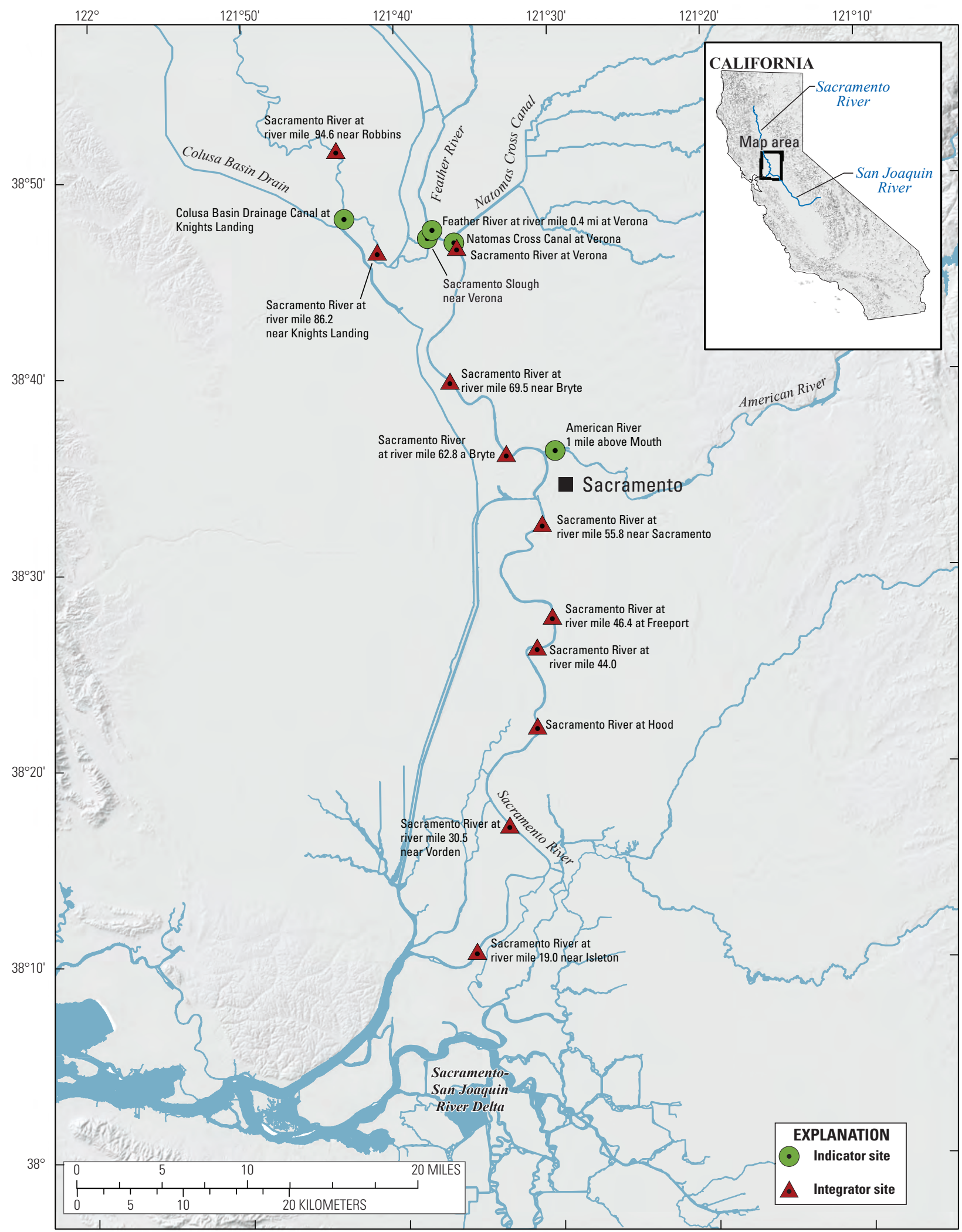

Base modified from U.S. Geological Survey and other Federal and State digital data various scales; Albers Equal Area Conic projection, standard parallels are $29^{\circ} 30^{\prime} \mathrm{N}$. and $45^{\circ} 30^{\prime}$ N.; North American Datum of 1983

Figure 1. Locations of indicator and integrator sampling sites in the lower Sacramento River watershed, California. 


\section{Study Area}

The Sacramento River watershed spans nearly 70,000 square kilometers $\left(\mathrm{km}^{2}\right)$ in central northern California and extends from the Delta to the Oregon border (California Department of Water Resources, 1993). The Sacramento River flows southward down the northern half of the Central Valley known as the Sacramento Valley. Land cover is largely forest in the mountainous upper headwaters of the basin, whereas agriculture dominates land use in the valley (approximately $5,128 \mathrm{~km}^{2}$, U.S. Geological Survey, 2014). Major crops by area include rice, alfalfa, almonds, peaches, prunes, and walnuts. Because of the intense levels of cultivation, irrigated and urban water use, and population (roughly 2 million people, U.S. Census Bureau, 2011), the Sacramento River and its tributaries flowing through the valley are subject to inputs from agricultural and urban runoff, discharge from storm drains, and wastewater treatment-plant effluents at many locations; thus, there is increased risk for elevated pesticide concentrations in the valley's surface waters (Domagalski and Dileanis, 2000).

\section{Procedures and Methods}

Basic water-quality parameters (water temperature, specific conductance, $\mathrm{pH}$, and dissolved oxygen concentration) were measured at the time of sample collection (table 2). Water samples were transported to the USGS Organic Chemistry Research Laboratory (OCRL) in Sacramento, California, and analyzed for a suite of 162 current-use pesticides using two methods: (1) gas chromatography with mass spectrometry (GC/MS) and (2) liquid chromatography with tandem mass spectrometry (LC/MS/MS). Extensive quality-control (QC) sampling was also performed for each method, including field blanks, field replicates, and laboratory matrix-spike and matrix-spike-replicate samples.

\section{Sample Collection}

Surface-water samples were collected by Regional San staff from the lower Sacramento River and its tributaries at 16 sites (table 1) in May and October 2016. Samples were collected in accordance with the Surface Water Ambient Monitoring program (SWAMP; California State Water Resources Control Board, 2014) protocols, with samples collected mid-channel at 0.5 -meter $(\mathrm{m})$ depth using a peristaltic pump from the Regional San's research vessel. Environmental and quality-control grab samples were collected in 1-liter baked amber bottles from all sites over a 5-day period. Following collection, samples were placed on ice and transported to the USGS OCRL for extraction and analysis.

\section{Pesticide Extraction and Analysis}

Extraction and analysis were performed in the laboratory within 24 hours of sample collection. Water samples were filtered through pre-weighed, baked 0.7-micrometer $(\mu \mathrm{m})$ glass-fiber filters (Grade GF/F, Whatman, Piscataway, New Jersey) to remove suspended material. The filter papers containing the suspended sediments were dried at room temperature overnight (in the dark), then stored in a freezer at -20 degrees Celsius $\left({ }^{\circ} \mathrm{C}\right)$ until extraction.

\section{Sample Extraction}

The full extraction procedure and instrumental analysis by LC/MS/MS is described in Hladik and Calhoun (2012). Filtered water samples were spiked with the recovery surrogate standards monuron (Chem Service, West Chester, Pennsylvania) and imidacloprid- $\mathrm{d}_{4}$ (Cambridge Isotope Laboratories, Andover, Massachusetts). Each sample was then passed through an Oasis Hydrophilic Lipophilic Balance (HLB) solid-phase extraction (SPE; 6 milliliters [mL], 500 milligrams [mg]; Waters, Milford, Massachusetts) cartridge that had been cleaned with one column volume of dichloromethane (DCM), followed by one column volume of acetone and two column volumes of deionized water. During this process, the water samples were pumped through the SPE cartridge at a flow rate of 10 milliliters per minute $(\mathrm{mL} / \mathrm{min})$; the cartridge was then dried under nitrogen gas until the SPE sorbent was dry. The analytes were eluted with $10 \mathrm{~mL}$ of 50:50 DCM:acetone, and the eluent was then evaporated to less than $0.5 \mathrm{~mL}$ using a gentle stream of dry nitrogen gas, solventexchanged into acetonitrile, and further evaporated to $0.2 \mathrm{~mL}$. The internal standard $(20$ microliters $[\mathrm{uL}]$ of a 5-nanogram per microliter $[\mathrm{ng} / \mu \mathrm{L}]$ solution of ${ }^{13} \mathrm{C}_{3}$-caffeine; Cambridge Isotope Laboratories) was then added to the sample. Lastly, the sample extracts were stored in a freezer at $-20{ }^{\circ} \mathrm{C}$ until analysis (up to 30 days). 
Table 2. Water-quality parameters measured in samples collected at surface-water sites in the Sacramento River watershed, California, May and October 2016.

[Numbers in brackets are U.S. Geological Survey (USGS) National Water Information System (NWIS) parameter codes. Abbreviations: hhmm, hours:minutes; $\mathrm{mg} / \mathrm{L}$, milligrams per liter; mm/dd/yyyy, month/day/year; ${ }^{\circ} \mathrm{C}$, degrees Celsius; $\mu \mathrm{S} / \mathrm{cm}$ at $25{ }^{\circ} \mathrm{C}$, microsiemens per centimeter at 25 degrees Celsius]

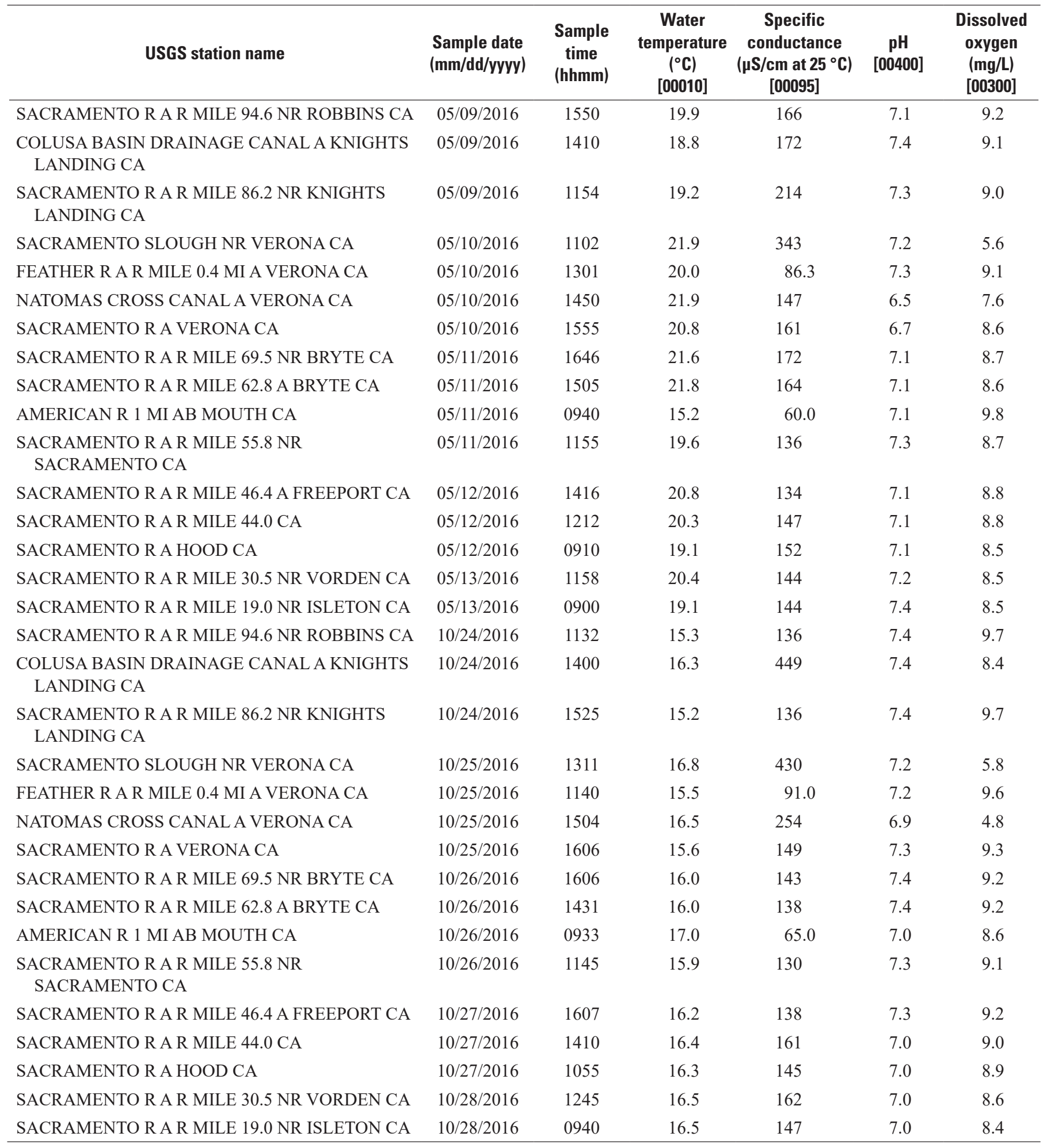


The full extraction procedure and instrumental analysis by GC/MS is described in (Hladik and others, 2008, 2009; Hladik and McWayne, 2012). Filtered-water samples were spiked with the recovery surrogate standard ${ }^{13} \mathrm{C}_{3}$-atrazine (Cambridge Isotope Laboratories). Each sample was passed through an Oasis HLB SPE (6 mL, $500 \mathrm{mg}$; Waters, Milford, Massachusetts) cartridge that had been cleaned with two column volumes of ethyl acetate (EtOAc), followed by two column volumes of methanol and two column volumes of deionized water. During this process, the water samples were pumped through the SPE cartridge at a flow rate of $10 \mathrm{~mL} / \mathrm{min}$, and the cartridge was then dried under nitrogen gas until the SPE sorbent was dry. After extraction, sodium sulfate was added to the sample bottle to remove any residual water, then the bottle was rinsed three times with approximately $2 \mathrm{~mL}$ of DCM into a collection tube. The bottle rinse was concentrated to $1 \mathrm{~mL}$ under a gentle stream of nitrogen gas. The SPE cartridge was dried under nitrogen gas until the SPE sorbent was dry, then the analytes were eluted with $12 \mathrm{~mL}$ of EtOAc into the concentrator tube containing its bottle rinse. The combined bottle rinse and eluent mixture was evaporated to less than $0.2 \mathrm{~mL}$ using a gentle stream of dry nitrogen gas. The internal standard $(20 \mu \mathrm{L}$ of a $10-\mathrm{ng} / \mu \mathrm{L}$ solution of the deuterated polycyclic aromatic hydrocarbon compounds acenaphthene- $\mathrm{d}_{10}$ and pyrene- $\mathrm{d}_{10}$ ) was then added to the sample. The sample extracts were stored in a freezer at $-20{ }^{\circ} \mathrm{C}$ until analysis (up to 30 days).

Filter papers were cut up and placed in an Erlenmeyer flask, spiked with the recovery surrogate standards $\mathrm{d}_{14}$-trifluralin, ${ }^{13} \mathrm{C}_{12}-p, p$ '-DDE, and ${ }^{13} \mathrm{C}_{6}$-permethrin (Cambridge Isotopes) and extracted twice with $50 \mathrm{~mL}$ of DCM in a sonicator (Branson 5200, Danbury, Connecticut) for 15 minutes. The extract was filtered through sodium sulfate, reduced using a Zymark Turbovap II evaporator (Hopkinton, Maryland) to $0.5 \mathrm{~mL}$, solvent exchanged into EtOAc, and further evaporated to less than $0.2 \mathrm{~mL}$ using a gentle stream of dry nitrogen gas. The internal standard $(20 \mu \mathrm{L}$ of a $10-\mathrm{ng} / \mu \mathrm{L}$ solution of the deuterated polycyclic aromatic hydrocarbon compounds acenaphthene- $\mathrm{d}_{10}$ and pyrene- $\mathrm{d}_{10}$ ) was then added to the sample. The sample extracts were stored in a freezer at $-20^{\circ} \mathrm{C}$ until analysis (up to 30 days).

\section{Analytical Methods}

Water extracts were analyzed by LC/MS/MS on an Agilent (Palo Alto, California) 1100 HPLC system coupled to a 6430 tandem MS system with a Zorbax Eclipse XDB-C18 column ( 2.1 by 150 by 3.5 millimeters [mm]). The column flow rate was $0.6 \mathrm{~mL} / \mathrm{min}$, and the column temperature was $30^{\circ} \mathrm{C}$. Data were collected in the multiple-reaction-monitoring mode. Additional details about the instrument method can be found in Hladik and Calhoun (2012).

Water and filter extracts were analyzed by GC/MS on an Agilent 7890A gas chromatograph with an Agilent 5975C Inert XL electron ionization (EI) mass-selective detector system using a DB-5MS analytical column (30 meters [m] by $0.25 \mathrm{~mm}$ by $0.25 \mu \mathrm{m}$ ) for separation with helium as the carrier gas. Data were collected in the selected ion-monitoring mode. Additional details of the GC/MS method can be found in Hladik and others $(2008,2009)$.

\section{Method Detection Limits}

Method detection limits (MDLs) for pesticide concentrations in surface water were validated in previous work (Hladik and others, 2008; Hladik and Calhoun, 2012) by using the procedure described in 40 CFR 136, Appendix B (U.S. Environmental Protection Agency, 1992). Method detection limits for pesticides in suspended sediments filtered from surface water were validated in previous studies by Hladik and others (2009) and Hladik and McWayne (2012). Method detection limits for pesticide concentrations measured in surface water are listed in table 3. Analytes can sometimes be identified at concentrations less than the MDLs with lower confidence in the numerical value; therefore, concentrations of compounds detected below the MDLs are reported as estimates. 
Table 3. Method detection limits for dissolved pesticides in surface water and on suspended sediments measured by the U.S. Geological Survey Organic Chemistry Research Laboratory.

[GC/MS, gas chromatography with mass spectrometry; LC/MS/MS, liquid chromatography with tandem mass spectrometry; ng/L, nanograms per liter; NWIS, National Water Information System]

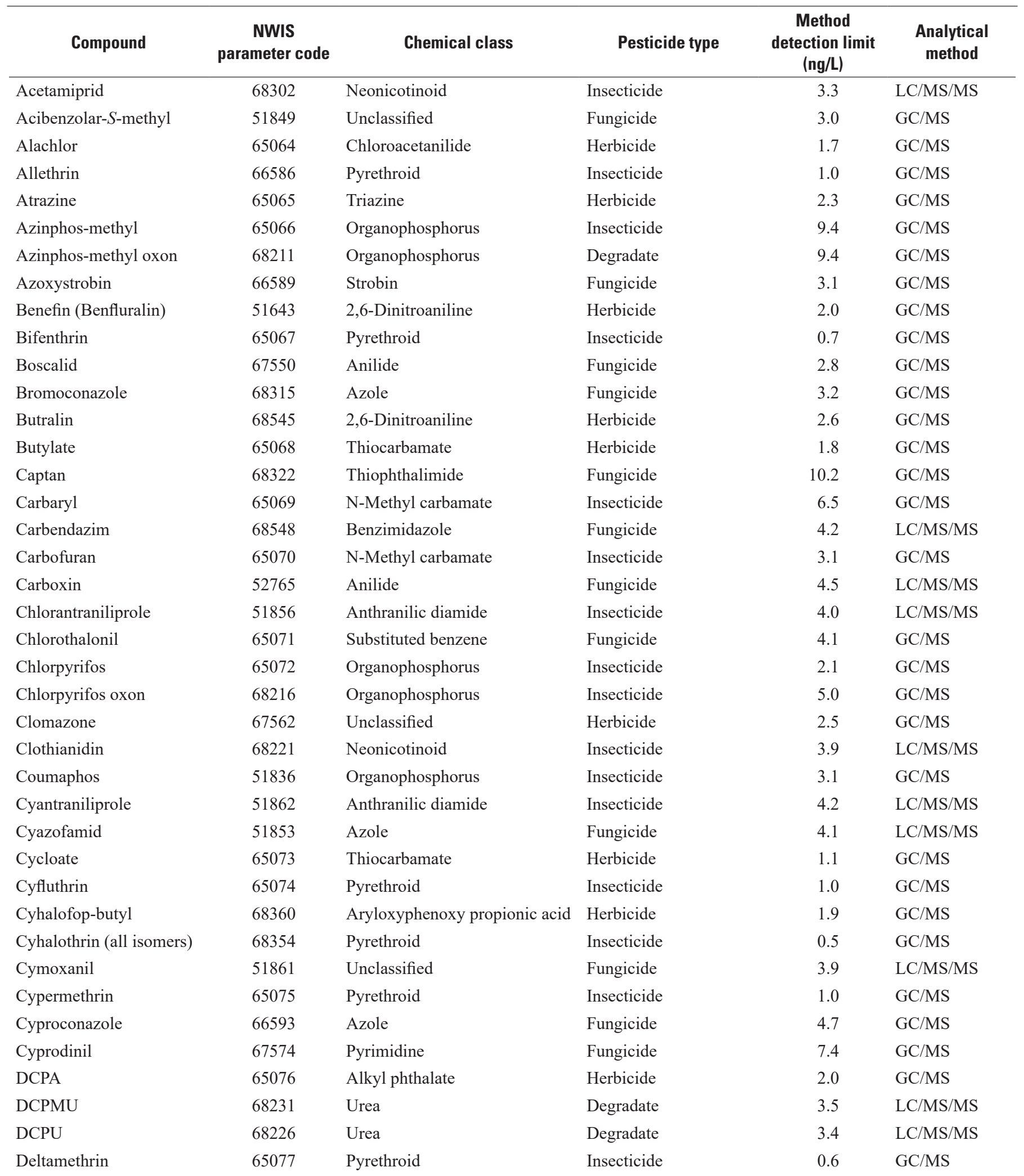


Table 3. Method detection limits for dissolved pesticides in surface water and on suspended sediments measured by the U.S. Geological Survey Organic Chemistry Research Laboratory.-Continued

[GC/MS, gas chromatography with mass spectrometry; LC/MS/MS, liquid chromatography with tandem mass spectrometry; ng/L, nanograms per liter; NWIS, National Water Information System]

\begin{tabular}{|c|c|c|c|c|c|}
\hline Compound & $\begin{array}{c}\text { NWIS } \\
\text { parameter code }\end{array}$ & Chemical class & Pesticide type & $\begin{array}{c}\text { Method } \\
\text { detection limit } \\
\text { (ng/L) }\end{array}$ & $\begin{array}{c}\text { Analytical } \\
\text { method }\end{array}$ \\
\hline Desthio-prothioconazole & 51865 & Unclassified & Degradate & 3.0 & $\mathrm{LC} / \mathrm{MS} / \mathrm{MS}$ \\
\hline Diazinon & 65078 & Organophosphorus & Insecticide & 0.9 & $\mathrm{GC} / \mathrm{MS}$ \\
\hline Diazoxon & 68236 & Organophosphorus & Degradate & 5.0 & GC/MS \\
\hline 3,4-Dichloroaniline & 66584 & Amine & Degradate & 3.2 & $\mathrm{LC} / \mathrm{MS} / \mathrm{MS}$ \\
\hline Difenoconazole & 67582 & Azole & Fungicide & 10.5 & GC/MS \\
\hline Dimethomorph & 68373 & Morpholine & Fungicide & 6.0 & GC/MS \\
\hline Dinotefuran & 68379 & Neonicotinoid & Insecticide & 4.5 & LC/MS/MS \\
\hline Dithiopyr & 51837 & Pyridinecarboxylic acid & Herbicide & 1.6 & $\mathrm{GC} / \mathrm{MS}$ \\
\hline Ethaboxam & 51855 & Unclassified & Fungicide & 3.8 & $\mathrm{LC} / \mathrm{MS} / \mathrm{MS}$ \\
\hline Ethalfluralin & 65082 & 2,6-Dinitroaniline & Herbicide & 3.0 & GC/MS \\
\hline Etofenprox & 67604 & Pyrethroid ether & Insecticide & 2.2 & $\mathrm{GC} / \mathrm{MS}$ \\
\hline Famoxadone & 67609 & Oxazolidinedione & Fungicide & 2.5 & GC/MS \\
\hline Fenamidone & 51848 & Imidazole & Fungicide & 5.1 & GC/MS \\
\hline Fenarimol & 67613 & Pyrimidine & Fungicide & 6.5 & $\mathrm{GC} / \mathrm{MS}$ \\
\hline Fenbuconazole & 67618 & Azole & Fungicide & 5.2 & GC/MS \\
\hline Fenhexamid & 67622 & Anilide & Fungicide & 7.6 & GC/MS \\
\hline Fenpropathrin & 65083 & Pyrethroid & Insecticide & 0.6 & GC/MS \\
\hline Fipronil sulfone & 66613 & Unclassified & Degradate & 3.5 & $\mathrm{GC} / \mathrm{MS}$ \\
\hline Flonicamid & 51858 & Unclassified & Insecticide & 3.4 & $\mathrm{LC} / \mathrm{MS} / \mathrm{MS}$ \\
\hline Fluazinam & 67636 & 2,6-Dinitroaniline & Fungicide & 4.4 & $\mathrm{GC} / \mathrm{MS}$ \\
\hline Fludioxonil & 67640 & Unclassified & Fungicide & 7.3 & GC/MS \\
\hline Flufenacet & 51840 & Anilide & Herbicide & 4.7 & $\mathrm{GC} / \mathrm{MS}$ \\
\hline Flumetralin & 51841 & 2,6-Dinitroaniline & Plant growth regulator & 5.8 & $\mathrm{GC} / \mathrm{MS}$ \\
\hline Fluopicolide & 51852 & Benzamide pyridine & Fungicide & 3.9 & GC/MS \\
\hline Fluopyram & 52761 & Amide & Fungicide & 3.8 & GC/MS \\
\hline Fluoxastrobin & 67645 & Strobin & Fungicide & 9.5 & GC/MS \\
\hline Flupyradifurone & 52764 & Butenolide & Insecticide & 3.0 & LC/MS/MS \\
\hline Fluridone & 51864 & Unclassified & Herbicide & 3.7 & LC/MS/MS \\
\hline Flusilazole & 67649 & Azole & Fungicide & 4.5 & GC/MS \\
\hline Flutolanil & 51842 & Anilide & Fungicide & 4.4 & GC/MS \\
\hline Flutriafol & 67653 & Azole & Fungicide & 4.2 & GC/MS \\
\hline
\end{tabular}


Table 3. Method detection limits for dissolved pesticides in surface water and on suspended sediments measured by the U.S. Geological Survey Organic Chemistry Research Laboratory.-Continued

[GC/MS, gas chromatography with mass spectrometry; LC/MS/MS, liquid chromatography with tandem mass spectrometry; ng/L, nanograms per liter; NWIS, National Water Information System]

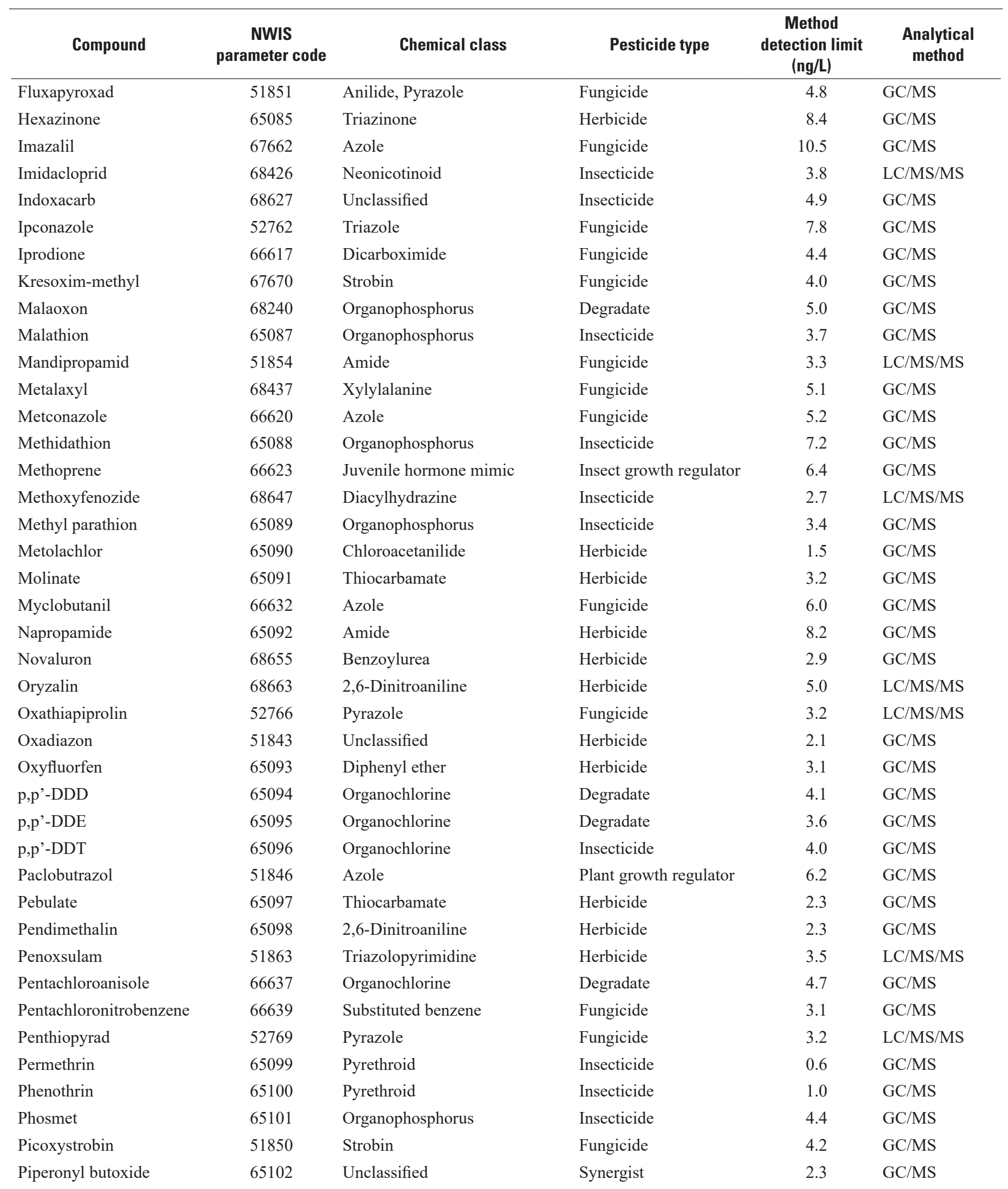


Table 3. Method detection limits for dissolved pesticides in surface water and on suspended sediments measured by the U.S. Geological Survey Organic Chemistry Research Laboratory.-Continued

[GC/MS, gas chromatography with mass spectrometry; LC/MS/MS, liquid chromatography with tandem mass spectrometry; ng/L, nanograms per liter; NWIS, National Water Information System]

\begin{tabular}{|c|c|c|c|c|c|}
\hline Compound & $\begin{array}{c}\text { NWIS } \\
\text { parameter code }\end{array}$ & Chemical class & Pesticide type & $\begin{array}{c}\text { Method } \\
\text { detection limit } \\
\text { (ng/L) }\end{array}$ & $\begin{array}{c}\text { Analytical } \\
\text { method }\end{array}$ \\
\hline Prodiamine & 51844 & 2,6-Dinitroaniline & Herbicide & 5.2 & GC/MS \\
\hline Prometon & 67702 & Triazine & Herbicide & 2.5 & GC/MS \\
\hline Prometryn & 65103 & Triazine & Herbicide & 1.8 & GC/MS \\
\hline Propanil & 66641 & Anilide & Herbicide & 10.1 & GC/MS \\
\hline Propiconazole & 66643 & Azole & Fungicide & 5.0 & GC/MS \\
\hline Propyzamide & 67706 & Amide & Herbicide & 5.0 & GC/MS \\
\hline Pyraclostrobin & 66646 & Strobin & Fungicide & 2.9 & GC/MS \\
\hline Pyridaben & 68682 & Unclassified & Insecticide & 5.4 & GC/MS \\
\hline Sedaxane & 52648 & Anilide, Pyrazole & Fungicide & 5.2 & GC/MS \\
\hline Simazine & 65105 & Triazine & Herbicide & 5.0 & GC/MS \\
\hline Sulfoxaflor & 52767 & Sulfoximine & Insecticide & 4.4 & $\mathrm{LC} / \mathrm{MS} / \mathrm{MS}$ \\
\hline tau-Fluvalinate & 65106 & Pyrethroid & Insecticide & 0.7 & GC/MS \\
\hline Tebuconazole & 66649 & Azole & Fungicide & 3.7 & $\mathrm{GC} / \mathrm{MS}$ \\
\hline Tebufenozide & 68692 & Moulting hormone agonist & Insecticide & 3.0 & $\mathrm{LC} / \mathrm{MS} / \mathrm{MS}$ \\
\hline Tebupirimfos & 68693 & Organophosphorus & Insecticide & 1.9 & GC/MS \\
\hline Tebupirimfos oxon & 68694 & Organophosphorus & Degradate & 2.8 & $\mathrm{GC} / \mathrm{MS}$ \\
\hline Tefluthrin & 67731 & Pyrethroid & Insecticide & 4.2 & GC/MS \\
\hline Thiazopyr & 51845 & Pyridinecarboxylic acid & Herbicide & 4.1 & GC/MS \\
\hline Thiobencarb & 65107 & Thiocarbamate & Herbicide & 1.9 & GC/MS \\
\hline Tolfenpyrad & 51866 & Pyrazole & Insecticide & 2.9 & $\mathrm{LC} / \mathrm{MS} / \mathrm{MS}$ \\
\hline Triadimefon & 67741 & Azole & Fungicide & 8.9 & GC/MS \\
\hline Triadimenol & 67746 & Azole & Fungicide & 8.0 & GC/MS \\
\hline Triallate & 68710 & Thiocarbamate & Herbicide & 2.4 & GC/MS \\
\hline Tribufos & 68711 & Organophosphorus & Defoliant & 3.1 & GC/MS \\
\hline Tricyclazole & 52768 & Azole & Fungicide & 4.1 & $\mathrm{LC} / \mathrm{MS} / \mathrm{MS}$ \\
\hline Trifloxystrobin & 66660 & Strobin & Fungicide & 4.7 & GC/MS \\
\hline Triflumizole & 67753 & Azole & Fungicide & 6.1 & GC/MS \\
\hline Trifluralin & 65108 & 2,6-Dinitroaniline & Herbicide & 2.1 & GC/MS \\
\hline Triticonazole & 67758 & Azole & Fungicide & 6.9 & GC/MS \\
\hline Zoxamide & 67768 & Amide & Fungicide & 3.5 & GC/MS \\
\hline
\end{tabular}




\section{Quality-Control Methods and Results}

Pesticide concentrations in water samples were validated against a comprehensive set of performance-based qualitycontrol samples, including field replicates, field blanks, matrix spikes, and matrix-spike replicates in accordance with the laboratory's Quality Assurance Project Plan (James Orlando, U.S. Geological Survey Organic Chemistry Research Laboratory, written commun., 2016) for California pesticide studies. Quality control samples were analyzed using the GC/MS and LC/MS/MS methods described earlier.

Four field blanks consisting of organic-free OCRL facility water, that was provided to the field sampling crew, were collected to demonstrate the cleanliness of field procedures. Two field blanks were collected at one site during each sampling period and analyzed by GC/MS and LC/MS/MS. No pesticides were detected in any of the blanks.

Four sequential field-replicate sample pairs were collected to test the reproducibility of results. Replicate pairs were collected at one site in each sampling period and analyzed by GC/MS and LC/MS/MS. There were 12 detections of pesticides in the sample pairs, and the relative standard deviation between the replicate and the complementary environmental sample was less than the control limit of 25 percent in all cases. The correlation of pesticide detections between the environmental and replicate samples was 100 percent.

Four laboratory matrix spikes, each paired with a matrix-spike-replicate, were analyzed to assess pesticide recovery, degradation, sorption, and interferences caused by the sampling matrix. Matrix spike and matrix-spikereplicate pairs were analyzed in samples collected at one site in each sampling period and analyzed by GC/MS and LC/MS/MS. All samples met the data-quality objective of 70-130 percent recovery of the matrix-spike compounds. The relative standard deviation between the matrix-spike samples and their complementary replicates was less than the 25-percent control limit in all cases.

\section{Results}

A variety of pesticide types, concentrations, and mixtures were detected in the water samples collected from the lower Sacramento River and five of its tributaries during this study. A total of 27 pesticides and pesticide degradates were detected in the water samples: 12 herbicides, 9 insecticides, 5 fungicides, and 1 synergist (fig. 2; table 4). Estimated concentration values (less than the individual compound MDL) are included in all the detection frequency and concentration data (table 5). At least one pesticide was detected in each water sample collected in May and October 2016. Mixtures of 2 or more pesticides were detected at 15 sites in May and
13 sites in October. Most of the pesticides detected in this study were herbicides (63 percent), whereas fungicides and insecticides represented 22 percent and 14 percent of the total detections, respectively. The compounds detected most frequently in the May and October sampling periods were the herbicides hexazinone (detected in 88 percent of the samples), diuron (84 percent), and the fungicide azoxystrobin (84 percent; table 5). Two pesticide compounds (clomazone and thiobencarb) were detected in three suspended-sediment samples filtered from the water samples collected from the three agricultural drainage sites (table 6). Concentrations of pesticides in suspended sediments are provided in nanograms per liter (ng/L) to facilitate the approximation of a wholewater pesticide concentration by summing the dissolved- and suspended-sediment concentrations of pesticides (table 6).

During this study, many of the pesticides and pesticide degradates detected at relatively high concentrations were those associated with use on rice crops (azoxystrobin, clomazone, and thiobencarb). Many of these elevated concentrations were detected in samples from the agricultural drainage sites (Colusa Basin Drainage Canal, Sacramento Slough, and Natomas Cross Canal) and also downstream in the Sacramento River at lower concentrations. These agricultural drainage indicator sites had average pesticide concentrations greater than those in the larger tributaries. The American River indicator site had the fewest total pesticide detections in this study and aside from the herbicide hexazinone, no pesticides were detected during the May sampling event, and none of the rice herbicides were detected here during either sampling event. Pesticide concentrations were relatively low at the Feather River and American River indicator sites during both sampling events.

During the May sampling event, the fungicides boscalid and azoxystrobin (both with 94 percent detection frequency); the herbicides clomazone, diuron, and hexazinone (all 94 percent); thiobencarb (88 percent); and metolachlor (81 percent) were the most frequently detected pesticides in the water samples (fig. 3; table 5). Pesticide concentrations ranged from below the MDLs to $576 \mathrm{ng} / \mathrm{L}$ (clomazone, fig. 4). The herbicide clomazone was frequently detected at concentrations above $100 \mathrm{ng} / \mathrm{L}$. Average pesticide concentrations and the average number of pesticide detections at the agricultural drainage indicator sites were 77 and 41 percent greater than those in the Sacramento River integrator sites, respectively. Two pesticides (clomazone and thiobencarb) were detected in three suspended sediment samples (table 6) filtered from water samples with both relatively high dissolved pesticide concentrations (greater than $300 \mathrm{ng} / \mathrm{L}$ ) and relatively large amounts of suspended sediments (greater than 0.030 gram). All pesticides were detected at concentrations lower than the U.S. Environmental Protection Agency's aquatic life benchmarks (U.S. Environmental Protection Agency, 2017). 


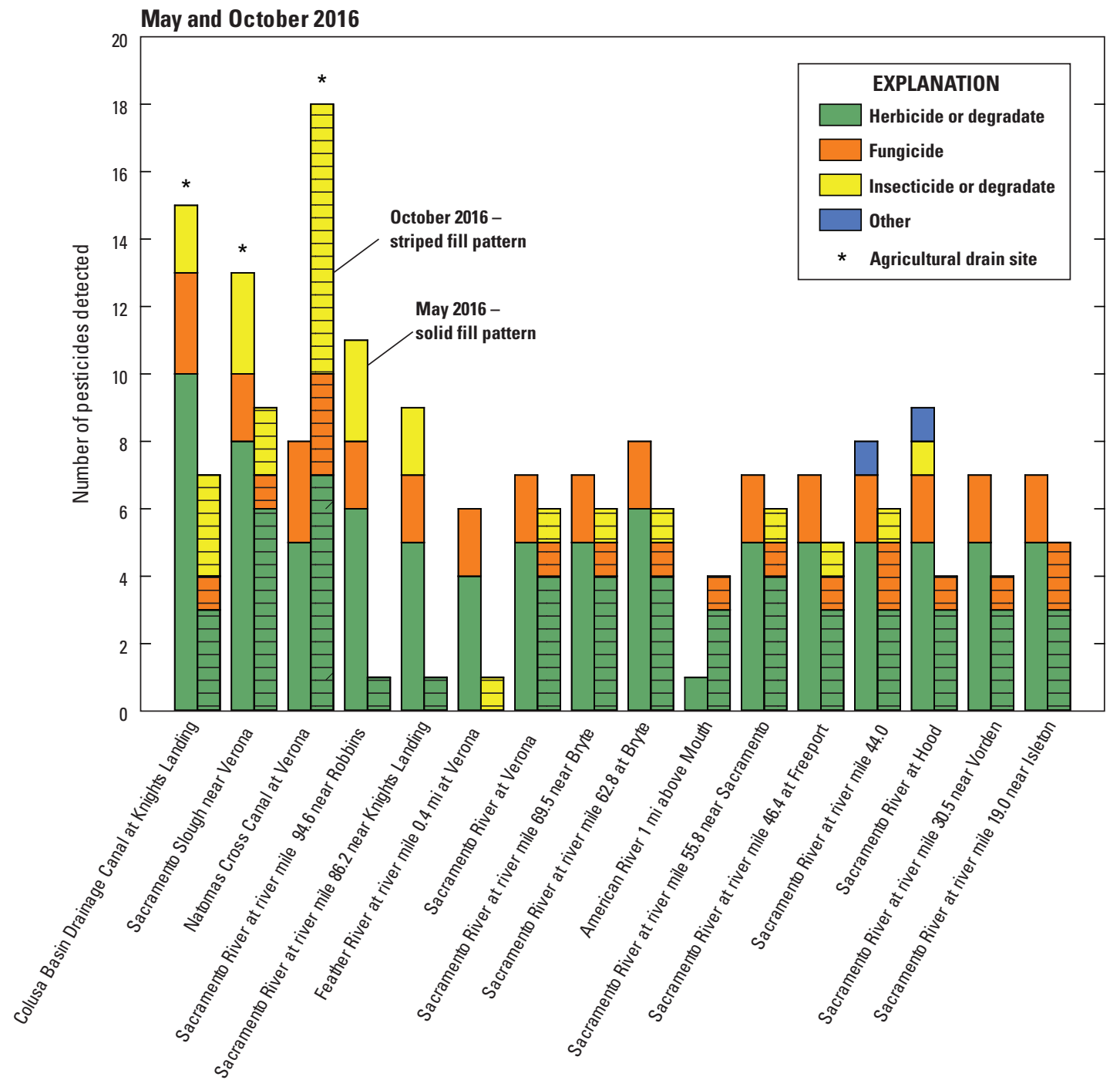

Figure 2. Number of pesticides detected at sites in the Sacramento River watershed, California, during May and October 2016. 
Table 4. Pesticide concentrations in surface-water samples collected in the Sacramento River watershed, California, May and 0ctober 2016.

[Numbers in brackets are U.S. Geological Survey (USGS) National Water Information System (NWIS) parameter codes. Concentrations are in nanograms per liter (ng/L). Results in parentheses ( ) are below method detection limits and are estimates. The following compounds were analyzed but were not detected in any samples: 3,5-dichloroaniline, acetamiprid, acibenzolar-methyl, alachlor, allethrin, atrazine, azinphos methyl, azinphos methyl oxon, benfluralin, bifenthrin, bromuconazole, butralin, butylate, captan, carbaryl, carbofuran, carboxin, chlorothalonil, chlorpyrifos, chlorpyrifos oxon, clothianidin, coumaphos, cyantraniliprole, cyazofamid, cycloate, cyfluthrin, cyhalofop-butyl, cyhalothrin, cymoxanil, cypermethrin, cyproconazole, cyprodinil, DCPA, deltamethrin, desthioprothioconazole, diazinon, diazinon oxon, difenconazole, dimethomorph, dinotefuran, EPTC, esfenvalerate, ethaboxam, ethalfluralin, etofenprox, famoxadone, fenamidone, fenarimol, fenbuconazole, fenhexamide, fenpropathrin, fenpyroximate, fenthion, fipronil desulfinyl amide, flonicamid, fluazinam, fludioxinil, flufenacet, flumetralin, fluopicolide, fluopyram, fluoxastrobin, flusilazole, flutolanil, flutriafol, imazalil, indoxacarb, ipconazole, iprodione, kresoxim-methyl, malathion, malathion oxon, mandipropamid, metalaxyl, metconazole, methidathion, methoprene, methyl parathion, molinate, myclobutanil, napropamide, novaluron, oryzalin, oxydiazon, oxyfluorfen, p,p'-DDE, p,p'-DDT, paclobutrazol, pentachloroaniline, pentachloroanisole, pebulate, pendimethalin, penthiopyrad, permethrin, phenothrin, phosmet, picoxystrobin, prodiamine, prometon, prometryn, propanil, propargite, propiconazole, propyzamide, pyraclostrobin, pyridaben, pyrimethanil, quinoxyfen, resmethrin, sedaxane, sulfoxaflor, tau-fluvalinate, tebuconazole, tebufenozide, tebupirimfos, tebupirimfos oxon, tefluthrin, tetraconazole, tetradifon, tetramethrin, thiabendazole, thiacloprid, thiamethoxam, thiazopyr, tolfenpyrad, triadimefon, triadimenol, triallate, tribufos, tricyclazole, trifloxystrobin, triflumizole, trifluralin, triticonazole, and zoxamide. Abbreviations: hhmm, hours:minutes; mm/dd/yyyy, month/day/year; —, not detected]

\begin{tabular}{|c|c|c|c|c|c|c|c|c|c|}
\hline USGS station name & $\begin{array}{l}\text { Sample date } \\
\text { (mm/dd/yyyy) }\end{array}$ & $\begin{array}{l}\text { Sample } \\
\text { time } \\
\text { (hhmm) }\end{array}$ & $\begin{array}{c}\text { 3,4-Dichloro- } \\
\text { aniline } \\
\text { [66584] }\end{array}$ & $\begin{array}{c}\text { Azoxys- } \\
\text { trobin } \\
\text { [66589] }\end{array}$ & $\begin{array}{c}\text { Boscalid } \\
\text { [67550] }\end{array}$ & $\begin{array}{l}\text { Carben- } \\
\text { dazim } \\
\text { [68548] }\end{array}$ & $\begin{array}{c}\text { Chlorantra- } \\
\text { niliprole } \\
\text { [51856] }\end{array}$ & $\begin{array}{c}\text { Clomazone } \\
\text { [67562] }\end{array}$ & $\begin{array}{l}\text { DCPMU } \\
\text { [68231] }\end{array}$ \\
\hline \multicolumn{10}{|c|}{ May 2016} \\
\hline SACRAMENTO R A R MILE 94.6 NR ROBBINS CA & $05 / 09 / 2016$ & 1550 & - & 6.7 & 7.7 & - & 4.0 & 70.1 & - \\
\hline COLUSA BASIN DRAINAGE CANAL A KNIGHTS LANDING CA & $05 / 09 / 2016$ & 1410 & 19.1 & 140.0 & 29.5 & - & 8.9 & 538.0 & 7.4 \\
\hline SACRAMENTO R A R MILE 86.2 NR KNIGHTS LANDING CA & $05 / 09 / 2016$ & 1154 & - & 43.8 & 22.4 & - & 6.2 & 129.1 & - \\
\hline SACRAMENTO SLOUGH NR VERONA CA & 05/10/2016 & 1102 & 8.1 & 85.1 & 13.6 & - & 4.0 & 576.3 & 4.1 \\
\hline FEATHER R A R MILE 0.4 MI A VERONA CA & 05/10/2016 & 1301 & - & 9.1 & 9.1 & - & - & 79.6 & - \\
\hline NATOMAS CROSS CANAL A VERONA CA & 05/10/2016 & 1450 & - & 23.2 & 5.1 & 8.6 & - & 301.0 & 6.9 \\
\hline SACRAMENTO R A VERONA CA & 05/10/2016 & 1555 & - & 37.2 & 5.2 & - & - & 134.8 & - \\
\hline SACRAMENTO R A R MILE 69.5 NR BRYTE CA & $05 / 11 / 2016$ & 1646 & - & 49.4 & 7.1 & - & - & 162.2 & - \\
\hline SACRAMENTO R A R MILE 62.8 A BRYTE CA & $05 / 11 / 2016$ & 1505 & 5.3 & 45.3 & 6.5 & - & - & 143.4 & - \\
\hline AMERICAN R 1 MI AB MOUTH CA & $05 / 11 / 2016$ & 0940 & - & - & - & - & - & - & - \\
\hline SACRAMENTO R A R MILE 55.8 NR SACRAMENTO CA & $05 / 11 / 2016$ & 1155 & - & 38.7 & 5.5 & - & - & 105.0 & - \\
\hline SACRAMENTO R A R MILE 46.4 A FREEPORT CA & $05 / 12 / 2016$ & 1416 & - & 32.6 & 5.3 & - & - & 111.3 & - \\
\hline SACRAMENTO R A R MILE 44.0 CA & $05 / 12 / 2016$ & 1212 & - & 32.6 & 4.9 & - & - & 110.3 & - \\
\hline SACRAMENTO R A HOOD CA & $05 / 12 / 2016$ & 0910 & - & 29.6 & 4.9 & - & - & 103.3 & - \\
\hline SACRAMENTO R A R MILE 30.5 NR VORDEN CA & $05 / 13 / 2016$ & 1158 & - & 30.4 & 5.1 & - & - & 116.8 & - \\
\hline SACRAMENTO R A R MILE 19.0 NR ISLETON CA & 05/13/2016 & 0900 & - & 31.4 & 5.6 & - & - & 104.2 & - \\
\hline \multicolumn{10}{|c|}{ October 2016} \\
\hline SACRAMENTO R A R MILE 94.6 NR ROBBINS CA & $10 / 24 / 2016$ & 1132 & - & - & - & - & - & - & - \\
\hline COLUSA BASIN DRAINAGE CANAL A KNIGHTS LANDING CA & $10 / 24 / 2016$ & 1400 & 11.4 & 66.2 & - & - & 5.4 & - & $(2.7)$ \\
\hline SACRAMENTO R A R MILE 86.2 NR KNIGHTS LANDING CA & $10 / 24 / 2016$ & 1525 & - & - & - & - & - & - & - \\
\hline SACRAMENTO SLOUGH NR VERONA CA & $10 / 25 / 2016$ & 1311 & 24.0 & 58.7 & - & - & $(3.4)$ & - & 48.8 \\
\hline FEATHER R A R MILE 0.4 MI A VERONA CA & $10 / 25 / 2016$ & 1140 & - & - & - & - & - & - & - \\
\hline NATOMAS CROSS CANAL A VERONA CA & $10 / 25 / 2016$ & 1504 & 9.3 & 14.6 & - & 14.2 & $(3.3)$ & - & 3.8 \\
\hline
\end{tabular}


[Numbers in brackets are U.S. Geological Survey (USGS) National Water Information System (NWIS) parameter codes. Concentrations are in nanograms per liter (ng/L). Results in parentheses ( ) are below method detection limits and are estimates. The following compounds were analyzed but were not detected in any samples: 3,5-dichloroaniline, acetamiprid, acibenzolar-methyl, alachlor, allethrin, atrazine, azinphos methyl, azinphos methyl oxon, benfluralin, bifenthrin, bromuconazole, butralin, butylate, captan, carbaryl, carbofuran, carboxin, chlorothalonil, chlorpyrifos, chlorpyrifos oxon, clothianidin,

coumaphos, cyantraniliprole, cyazofamid, cycloate, cyfluthrin, cyhalofop-butyl, cyhalothrin, cymoxanil, cypermethrin, cyproconazole, cyprodinil, DCPA, deltamethrin, desthioprothioconazole, diazinon, diazinon oxon, difenconazole, dimethomorph, dinotefuran, EPTC, esfenvalerate, ethaboxam, ethalfluralin, etofenprox, famoxadone, fenamidone, fenarimol, fenbuconazole, fenhexamide, fenpropathrin, fenpyroximate, fenthion, fipronil desulfinyl amide, flonicamid, fluazinam, fludioxinil, flufenacet, flumetralin, fluopicolide, fluopyram, fluoxastrobin, flusilazole, flutolanil, flutriafol, imazalil, indoxacarb, ipconazole, iprodione, kresoxim-methyl, malathion, malathion oxon, mandipropamid, metalaxyl, metconazole, methidathion, methoprene, methyl parathion, molinate, myclobutanil, napropamide, novaluron, oryzalin, oxydiazon, oxyfluorfen, p,p'-DDE, p,p'-DDT, paclobutrazol, pentachloroaniline, pentachloroanisole, pebulate, pendimethalin, penthiopyrad, permethrin, phenothrin, phosmet, picoxystrobin, prodiamine, prometon, prometryn, propanil, propargite, propiconazole, propyzamide, pyraclostrobin, pyridaben, pyrimethanil, quinoxyfen, resmethrin, sedaxane, sulfoxaflor, tau-fluvalinate, tebuconazole, tebufenozide, tebupirimfos, tebupirimfos oxon, tefluthrin, tetraconazole, tetradifon, tetramethrin, thiabendazole, thiacloprid, thiamethoxam, thiazopyr, tolfenpyrad, triadimefon, triadimenol, triallate, tribufos, tricyclazole, trifloxystrobin, triflumizole, trifluralin, triticonazole, and zoxamide. Abbreviations: hhmm, hours:minutes; mm/dd/yyyy, month/day/year; -, not detected]

\begin{tabular}{|c|c|c|c|c|c|c|c|c|c|}
\hline USGS station name & $\begin{array}{l}\text { Sample date } \\
\text { (mm/dd/yyyy) }\end{array}$ & $\begin{array}{l}\text { Sample } \\
\text { time } \\
\text { (hhmm) }\end{array}$ & $\begin{array}{l}\text { 3-Dichloro- } \\
\text { aniline } \\
\text { [66584] }\end{array}$ & $\begin{array}{c}\text { Azoxys- } \\
\text { trobin } \\
\text { [66589] }\end{array}$ & $\begin{array}{c}\text { Boscalid } \\
\text { [67550] }\end{array}$ & $\begin{array}{l}\text { Carben- } \\
\text { dazim } \\
\text { [68548] }\end{array}$ & $\begin{array}{l}\text { Chlorantra- } \\
\text { niliprole } \\
\text { [51856] }\end{array}$ & $\begin{array}{c}\text { Clomazone } \\
\text { [67562] }\end{array}$ & $\begin{array}{l}\text { DCPMU } \\
\text { [68231] }\end{array}$ \\
\hline \multicolumn{10}{|c|}{ October 2016-Continued } \\
\hline SACRAMENTO R A VERONA CA & $10 / 25 / 2016$ & 1606 & 4.3 & 3.8 & - & - & - & - & 4.3 \\
\hline SACRAMENTO R A R MILE 69.5 NR BRYTE CA & $10 / 26 / 2016$ & 1606 & 4.8 & 5.2 & - & - & - & - & 4.0 \\
\hline SACRAMENTO R A R MILE 62.8 A BRYTE CA & $10 / 26 / 2016$ & 1431 & 5.5 & 5.3 & - & - & - & - & 3.7 \\
\hline AMERICAN R 1 MI AB MOUTH CA & $10 / 26 / 2016$ & 0933 & - & - & - & 6.9 & - & - & 5.1 \\
\hline SACRAMENTO R A R MILE 55.8 NR SACRAMENTO CA & $10 / 26 / 2016$ & 1145 & 4.3 & $(2.3)$ & - & - & - & - & 4.0 \\
\hline SACRAMENTO R A R MILE 46.4 A FREEPORT CA & $10 / 27 / 2016$ & 1607 & 4.4 & 4.1 & - & - & - & - & - \\
\hline SACRAMENTO R A R MILE 44.0 CA & $10 / 27 / 2016$ & 1410 & 4.9 & 4.4 & - & 7.7 & - & - & - \\
\hline SACRAMENTO R A HOOD CA & $10 / 27 / 2016$ & 1055 & 3.9 & $(2.6)$ & - & - & - & - & - \\
\hline SACRAMENTO R A R MILE 30.5 NR VORDEN CA & $10 / 28 / 2016$ & 1245 & 7.5 & 5.5 & - & - & - & - & - \\
\hline SACRAMENTO R A R MILE 19.0 NR ISLETON CA & $10 / 28 / 2016$ & 0940 & 5.0 & $(2.3)$ & - & 4.9 & - & - & - \\
\hline USGS station name & $\begin{array}{l}\text { Sample date } \\
\text { (mm/dd/yyyy) }\end{array}$ & $\begin{array}{c}\text { Sample time } \\
\text { (hhmm) }\end{array}$ & $\begin{array}{c}\text { DCPU } \\
\text { [68226] }\end{array}$ & $\begin{array}{c}\text { Dithiopyr } \\
\text { [51837] }\end{array}$ & $\begin{array}{l}\text { Diuron } \\
\text { [66598] }\end{array}$ & $\begin{array}{c}\text { Fipronil } \\
\text { [66604] }\end{array}$ & $\begin{array}{c}\text { Fipronil } \\
\text { desulfinyl } \\
\text { [68891] } \\
\end{array}$ & $\begin{array}{l}\text { Fipronil } \\
\text { sulfide } \\
\text { [66610] }\end{array}$ & $\begin{array}{l}\text { Fipronil } \\
\text { sulfone } \\
\text { [66613] } \\
\end{array}$ \\
\hline \multicolumn{10}{|c|}{ May 2016-Continued } \\
\hline SACRAMENTO R A R MILE 94.6 NR ROBBINS CA & $05 / 09 / 2016$ & 1550 & - & - & 3.4 & - & - & - & - \\
\hline COLUSA BASIN DRAINAGE CANAL A KNIGHTS LANDING CA & 05/09/2016 & 1410 & $(3.2)$ & - & 24.2 & - & - & - & - \\
\hline SACRAMENTO R A R MILE 86.2 NR KNIGHTS LANDING CA & 05/09/2016 & 1154 & - & - & 4.8 & - & - & - & - \\
\hline SACRAMENTO SLOUGH NR VERONA CA & 05/10/2016 & 1102 & $(2.4)$ & - & 14.3 & - & - & - & - \\
\hline FEATHER R A R MILE 0.4 MI A VERONA CA & $05 / 10 / 2016$ & 1301 & - & - & 6.7 & - & - & - & - \\
\hline NATOMAS CROSS CANAL A VERONA CA & $05 / 10 / 2016$ & 1450 & - & - & 26.4 & - & - & - & - \\
\hline SACRAMENTO R A VERONA CA & $05 / 10 / 2016$ & 1555 & - & - & 8.6 & - & - & - & - \\
\hline SACRAMENTO R A R MILE 69.5 NR BRYTE CA & $05 / 11 / 2016$ & 1646 & - & - & 11.4 & - & - & - & - \\
\hline SACRAMENTO R A R MILE 62.8 A BRYTE CA & $05 / 11 / 2016$ & 1505 & - & - & 3.6 & - & - & - & - \\
\hline
\end{tabular}


Table 4. Pesticide concentrations in surface-water samples collected in the Sacramento River watershed, California, May and 0ctober 2016.-Continued

[Numbers in brackets are U.S. Geological Survey (USGS) National Water Information System (NWIS) parameter codes. Concentrations are in nanograms per liter (ng/L). Results in parentheses ( ) are below method detection limits and are estimates. The following compounds were analyzed but were not detected in any samples: 3,5-dichloroaniline, acetamiprid, acibenzolar-methyl, alachlor, allethrin, atrazine, azinphos methyl, azinphos methyl oxon, benfluralin, bifenthrin, bromuconazole, butralin, butylate, captan, carbaryl, carbofuran, carboxin, chlorothalonil, chlorpyrifos, chlorpyrifos oxon, clothianidin, coumaphos, cyantraniliprole, cyazofamid, cycloate, cyfluthrin, cyhalofop-butyl, cyhalothrin, cymoxanil, cypermethrin, cyproconazole, cyprodinil, DCPA, deltamethrin, desthioprothioconazole, diazinon, diazinon oxon, difenconazole, dimethomorph, dinotefuran, EPTC, esfenvalerate, ethaboxam, ethalfluralin, etofenprox, famoxadone, fenamidone, fenarimol, fenbuconazole, fenhexamide, fenpropathrin, fenpyroximate, fenthion, fipronil desulfinyl amide, flonicamid, fluazinam, fludioxinil, flufenacet, flumetralin, fluopicolide, fluopyram, fluoxastrobin, flusilazole, flutolanil, flutriafol, imazalil, indoxacarb, ipconazole, iprodione, kresoxim-methyl, malathion, malathion oxon, mandipropamid, metalaxyl, metconazole, methidathion, methoprene, methyl parathion, molinate, myclobutanil, napropamide, novaluron, oryzalin, oxydiazon, oxyfluorfen, p,p'-DDE, p,p'-DDT, paclobutrazol, pentachloroaniline, pentachloroanisole, pebulate, pendimethalin, penthiopyrad, permethrin, phenothrin, phosmet, picoxystrobin,

prodiamine, prometon, prometryn, propanil, propargite, propiconazole, propyzamide, pyraclostrobin, pyridaben, pyrimethanil, quinoxyfen, resmethrin, sedaxane, sulfoxaflor, tau-fluvalinate, tebuconazole, tebufenozide, tebupirimfos, tebupirimfos oxon, tefluthrin, tetraconazole, tetradifon, tetramethrin, thiabendazole, thiacloprid, thiamethoxam, thiazopyr, tolfenpyrad, triadimefon, triadimenol, triallate, tribufos, tricyclazole, trifloxystrobin, triflumizole, trifluralin, triticonazole, and zoxamide. Abbreviations: hhmm, hours:minutes; mm/dd/yyyy, month/day/year; —, not detected]

\begin{tabular}{|c|c|c|c|c|c|c|c|c|c|}
\hline USGS station name & $\begin{array}{l}\text { Sample date } \\
\text { (mm/dd/yyyy) }\end{array}$ & $\begin{array}{c}\text { Sample time } \\
\text { (hhmm) }\end{array}$ & $\begin{array}{c}\text { DCPU } \\
{[68226]}\end{array}$ & $\begin{array}{c}\text { Dithiopyr } \\
\text { [51837] }\end{array}$ & $\begin{array}{l}\text { Diuron } \\
{[66598]}\end{array}$ & $\begin{array}{c}\text { Fipronil } \\
\text { [66604] }\end{array}$ & $\begin{array}{c}\text { Fipronil } \\
\text { desulfinyl } \\
\text { [68891] }\end{array}$ & $\begin{array}{c}\text { Fipronil } \\
\text { sulfide } \\
\text { [66610] }\end{array}$ & $\begin{array}{l}\text { Fipronil } \\
\text { sulfone } \\
\text { [66613] }\end{array}$ \\
\hline \multicolumn{10}{|c|}{ May 2016-Continued } \\
\hline AMERICAN R 1 MI AB MOUTH CA & $05 / 11 / 2016$ & 0940 & - & - & - & - & - & - & - \\
\hline SACRAMENTO R A R MILE 55.8 NR SACRAMENTO CA & $05 / 11 / 2016$ & 1155 & - & - & 5.4 & - & - & - & - \\
\hline SACRAMENTO R A R MILE 46.4 A FREEPORT CA & $05 / 12 / 2016$ & 1416 & - & - & 3.7 & - & - & - & - \\
\hline SACRAMENTO R A R MILE 44.0 CA & $05 / 12 / 2016$ & 1212 & - & - & 4.4 & - & - & - & - \\
\hline SACRAMENTO R A HOOD CA & $05 / 12 / 2016$ & 0910 & - & - & 6.0 & - & - & - & - \\
\hline SACRAMENTO R A R MILE 30.5 NR VORDEN CA & $05 / 13 / 2016$ & 1158 & - & - & 5.0 & - & - & - & - \\
\hline SACRAMENTO R A R MILE 19.0 NR ISLETON CA & 05/13/2016 & 0900 & - & - & 3.3 & - & - & - & - \\
\hline \multicolumn{10}{|c|}{ October 2016-Continued } \\
\hline SACRAMENTO R A R MILE 94.6 NR ROBBINS CA & $10 / 24 / 2016$ & 1132 & - & - & - & - & - & - & - \\
\hline COLUSA BASIN DRAINAGE CANAL A KNIGHTS LANDING CA & $10 / 24 / 2016$ & 1400 & - & - & - & - & - & - & - \\
\hline SACRAMENTO R A R MILE 86.2 NR KNIGHTS LANDING CA & $10 / 24 / 2016$ & 1525 & - & - & - & - & - & - & - \\
\hline SACRAMENTO SLOUGH NR VERONA CA & $10 / 25 / 2016$ & 1311 & 6.5 & - & 326.0 & - & - & - & - \\
\hline FEATHER R A R MILE 0.4 MI A VERONA CA & $10 / 25 / 2016$ & 1140 & - & - & - & - & - & - & - \\
\hline NATOMAS CROSS CANAL A VERONA CA & $10 / 25 / 2016$ & 1504 & 6.3 & 26.2 & 17.0 & 3.6 & 8.8 & 3.0 & 8.8 \\
\hline SACRAMENTO R A VERONA CA & $10 / 25 / 2016$ & 1606 & - & - & 40.7 & - & - & - & - \\
\hline SACRAMENTO R A R MILE 69.5 NR BRYTE CA & $10 / 26 / 2016$ & 1606 & - & - & 12.2 & - & - & - & - \\
\hline SACRAMENTO R A R MILE 62.8 A BRYTE CA & $10 / 26 / 2016$ & 1431 & - & - & 10.6 & - & - & - & - \\
\hline AMERICAN R 1 MI AB MOUTH CA & $10 / 26 / 2016$ & 0933 & 9.3 & - & 25.2 & - & - & - & - \\
\hline SACRAMENTO R A R MILE 55.8 NR SACRAMENTO CA & $10 / 26 / 2016$ & 1145 & - & - & 23.7 & - & - & - & - \\
\hline SACRAMENTO R A R MILE 46.4 A FREEPORT CA & $10 / 27 / 2016$ & 1607 & - & - & 11.2 & - & - & - & - \\
\hline SACRAMENTO R A R MILE 44.0 CA & $10 / 27 / 2016$ & 1410 & - & - & 15.4 & - & - & - & - \\
\hline SACRAMENTO R A HOOD CA & $10 / 27 / 2016$ & 1055 & - & - & 13.2 & - & - & - & - \\
\hline SACRAMENTO R A R MILE 30.5 NR VORDEN CA & $10 / 28 / 2016$ & 1245 & - & - & 12.1 & - & - & - & - \\
\hline SACRAMENTO R A R MILE 19.0 NR ISLETON CA & $10 / 28 / 2016$ & 0940 & - & - & 14.1 & - & - & - & - \\
\hline
\end{tabular}


[Numbers in brackets are U.S. Geological Survey (USGS) National Water Information System (NWIS) parameter codes. Concentrations are in nanograms per liter (ng/L). Results in parentheses ( ) are below method detection limits and are estimates. The following compounds were analyzed but were not detected in any samples: 3,5-dichloroaniline, acetamiprid, acibenzolar-methyl, alachlor, allethrin, atrazine, azinphos methyl, azinphos methyl oxon, benfluralin, bifenthrin, bromuconazole, butralin, butylate, captan, carbaryl, carbofuran, carboxin, chlorothalonil, chlorpyrifos, chlorpyrifos oxon, clothianidin, coumaphos, cyantraniliprole, cyazofamid, cycloate, cyfluthrin, cyhalofop-butyl, cyhalothrin, cymoxanil, cypermethrin, cyproconazole, cyprodinil, DCPA, deltamethrin, desthioprothioconazole, diazinon, diazinon oxon, difenconazole, dimethomorph, dinotefuran, EPTC, esfenvalerate, ethaboxam, ethalfluralin, etofenprox, famoxadone, fenamidone, fenarimol, fenbuconazole, fenhexamide, fenpropathrin, fenpyroximate, fenthion, fipronil desulfinyl amide, flonicamid, fluazinam, fludioxinil, flufenacet, flumetralin, fluopicolide, fluopyram, fluoxastrobin, flusilazole, flutolanil, flutriafol, imazalil, indoxacarb, ipconazole, iprodione, kresoxim-methyl, malathion, malathion oxon, mandipropamid, metalaxyl, metconazole, methidathion, methoprene, methyl parathion, molinate, myclobutanil, napropamide, novaluron, oryzalin, oxydiazon, oxyfluorfen, p,p'-DDE, p,p'-DDT, paclobutrazol, pentachloroaniline, pentachloroanisole, pebulate, pendimethalin, penthiopyrad, permethrin, phenothrin, phosmet, picoxystrobin, prodiamine, prometon, prometryn, propanil, propargite, propiconazole, propyzamide, pyraclostrobin, pyridaben, pyrimethanil, quinoxyfen, resmethrin, sedaxane, sulfoxaflor, tau-fluvalinate, tebuconazole, tebufenozide, tebupirimfos, tebupirimfos oxon, tefluthrin, tetraconazole, tetradifon, tetramethrin, thiabendazole, thiacloprid, thiamethoxam, thiazopyr, tolfenpyrad, triadimefon, triadimenol, triallate, tribufos, tricyclazole, trifloxystrobin, triflumizole, trifluralin, triticonazole, and zoxamide. Abbreviations: hhmm, hours:minutes; mm/dd/yyyy, month/day/year; —, not detected]

\begin{tabular}{|c|c|c|c|c|c|c|c|c|c|}
\hline USGS station name & $\begin{array}{l}\text { Sample date } \\
\text { (mm/dd/yyyy) }\end{array}$ & $\begin{array}{l}\text { Sample time } \\
\text { (hhmm) }\end{array}$ & $\begin{array}{c}\text { Flupyradi- } \\
\text { furone } \\
\text { [52764] }\end{array}$ & $\begin{array}{c}\text { Fluridone } \\
\text { [51864] }\end{array}$ & $\begin{array}{c}\text { Fluxa- } \\
\text { pyroxad } \\
{[51851]}\end{array}$ & $\begin{array}{l}\text { Hexa- } \\
\text { zinone } \\
{[65085]}\end{array}$ & $\begin{array}{c}\text { Imidaclo- } \\
\text { prid } \\
{[68426]}\end{array}$ & $\begin{array}{c}\text { Methoxy- } \\
\text { fenozide } \\
\text { [68647] }\end{array}$ & $\begin{array}{l}\text { Meto- } \\
\text { lachlor } \\
{[65090]}\end{array}$ \\
\hline \multicolumn{10}{|c|}{ May 2016-Continued } \\
\hline SACRAMENTO R A R MILE 94.6 NR ROBBINS CA & $05 / 09 / 2016$ & 1550 & - & - & - & 15.3 & $(2.6)$ & 6.7 & 12.8 \\
\hline COLUSA BASIN DRAINAGE CANAL A KNIGHTS LANDING CA & 05/09/2016 & 1410 & - & - & 13.6 & 16.5 & - & 8.0 & 78.3 \\
\hline SACRAMENTO R A R MILE 86.2 NR KNIGHTS LANDING CA & 05/09/2016 & 1154 & - & - & - & 15.3 & - & 5.7 & 27.2 \\
\hline SACRAMENTO SLOUGH NR VERONA CA & $05 / 10 / 2016$ & 1102 & - & - & - & 10.0 & $(3.4)$ & 4.8 & 64.4 \\
\hline FEATHER R A R MILE 0.4 MI A VERONA CA & $05 / 10 / 2016$ & 1301 & - & - & - & $(7.9)$ & - & - & - \\
\hline NATOMAS CROSS CANAL A VERONA CA & $05 / 10 / 2016$ & 1450 & - & - & - & - & - & - & - \\
\hline SACRAMENTO R A VERONA CA & $05 / 10 / 2016$ & 1555 & - & - & - & 10.4 & - & - & 15.2 \\
\hline SACRAMENTO R A R MILE 69.5 NR BRYTE CA & $05 / 11 / 2016$ & 1646 & - & - & - & 14.7 & - & - & 15.2 \\
\hline SACRAMENTO R A R MILE 62.8 A BRYTE CA & $05 / 11 / 2016$ & 1505 & - & - & - & 17.3 & - & - & 16.2 \\
\hline AMERICAN R 1 MI AB MOUTH CA & $05 / 11 / 2016$ & 0940 & - & - & - & 29.1 & - & - & - \\
\hline SACRAMENTO R A R MILE 55.8 NR SACRAMENTO CA & $05 / 11 / 2016$ & 1155 & - & - & - & 15.0 & - & - & 11.3 \\
\hline SACRAMENTO R A R MILE 46.4 A FREEPORT CA & $05 / 12 / 2016$ & 1416 & - & - & - & 16.1 & - & - & 10.7 \\
\hline SACRAMENTO R A R MILE 44.0 CA & $05 / 12 / 2016$ & 1212 & - & - & - & 16.1 & - & - & 11.2 \\
\hline SACRAMENTO R A HOOD CA & $05 / 12 / 2016$ & 0910 & - & - & - & 15.3 & $(2.7)$ & - & 11.3 \\
\hline SACRAMENTO R A R MILE 30.5 NR VORDEN CA & $05 / 13 / 2016$ & 1158 & - & - & - & 18.1 & - & - & 11.4 \\
\hline SACRAMENTO R A R MILE 19.0 NR ISLETON CA & $05 / 13 / 2016$ & 0900 & - & - & - & 14.4 & - & - & 12.1 \\
\hline \multicolumn{10}{|c|}{ October 2016-Continued } \\
\hline SACRAMENTO R A R MILE 94.6 NR ROBBINS CA & $10 / 24 / 2016$ & 1132 & - & - & - & 29.5 & - & - & - \\
\hline COLUSA BASIN DRAINAGE CANAL A KNIGHTS LANDING CA & $10 / 24 / 2016$ & 1400 & 4.7 & - & - & 33.7 & - & 52.0 & - \\
\hline SACRAMENTO R A R MILE 86.2 NR KNIGHTS LANDING CA & $10 / 24 / 2016$ & 1525 & - & - & - & 27.8 & - & - & - \\
\hline SACRAMENTO SLOUGH NR VERONA CA & $10 / 25 / 2016$ & 1311 & - & - & - & 13.2 & - & 41.7 & - \\
\hline FEATHER R A R MILE 0.4 MI A VERONA CA & $10 / 25 / 2016$ & 1140 & - & - & - & - & - & 5.8 & - \\
\hline NATOMAS CROSS CANAL A VERONA CA & $10 / 25 / 2016$ & 1504 & - & $(3.4)$ & - & - & 6.1 & 7.4 & - \\
\hline
\end{tabular}


Table 4. Pesticide concentrations in surface-water samples collected in the Sacramento River watershed, California, May and 0ctober 2016.-Continued

[Numbers in brackets are U.S. Geological Survey (USGS) National Water Information System (NWIS) parameter codes. Concentrations are in nanograms per liter (ng/L). Results in parentheses ( ) are below method detection limits and are estimates. The following compounds were analyzed but were not detected in any samples: 3,5-dichloroaniline, acetamiprid, acibenzolar-methyl, alachlor, allethrin, atrazine, azinphos methyl, azinphos methyl oxon, benfluralin, bifenthrin, bromuconazole, butralin, butylate, captan, carbaryl, carbofuran, carboxin, chlorothalonil, chlorpyrifos, chlorpyrifos oxon, clothianidin, coumaphos, cyantraniliprole, cyazofamid, cycloate, cyfluthrin, cyhalofop-butyl, cyhalothrin, cymoxanil, cypermethrin, cyproconazole, cyprodinil, DCPA, deltamethrin, desthioprothioconazole, diazinon, diazinon oxon, difenconazole, dimethomorph, dinotefuran, EPTC, esfenvalerate, ethaboxam, ethalfluralin, etofenprox, famoxadone, fenamidone, fenarimol, fenbuconazole, fenhexamide, fenpropathrin, fenpyroximate, fenthion, fipronil desulfinyl amide, flonicamid, fluazinam, fludioxinil, flufenacet, flumetralin, fluopicolide, fluopyram, fluoxastrobin, flusilazole, flutolanil, flutriafol, imazalil, indoxacarb, ipconazole, iprodione, kresoxim-methyl, malathion, malathion oxon, mandipropamid, metalaxyl, metconazole, methidathion, methoprene, methyl parathion, molinate, myclobutanil, napropamide, novaluron, oryzalin, oxydiazon, oxyfluorfen, p,p'-DDE, p,p'-DDT, paclobutrazol, pentachloroaniline, pentachloroanisole, pebulate, pendimethalin, penthiopyrad, permethrin, phenothrin, phosmet, picoxystrobin, prodiamine, prometon, prometryn, propanil, propargite, propiconazole, propyzamide, pyraclostrobin, pyridaben, pyrimethanil, quinoxyfen, resmethrin, sedaxane, sulfoxaflor, tau-fluvalinate, tebuconazole, tebufenozide, tebupirimfos, tebupirimfos oxon, tefluthrin, tetraconazole, tetradifon, tetramethrin, thiabendazole, thiacloprid, thiamethoxam, thiazopyr, tolfenpyrad, triadimefon, triadimenol, triallate, tribufos, tricyclazole, trifloxystrobin, triflumizole, trifluralin, triticonazole, and zoxamide. Abbreviations: hhmm, hours:minutes; mm/dd/yyyy, month/day/year; —, not detected]

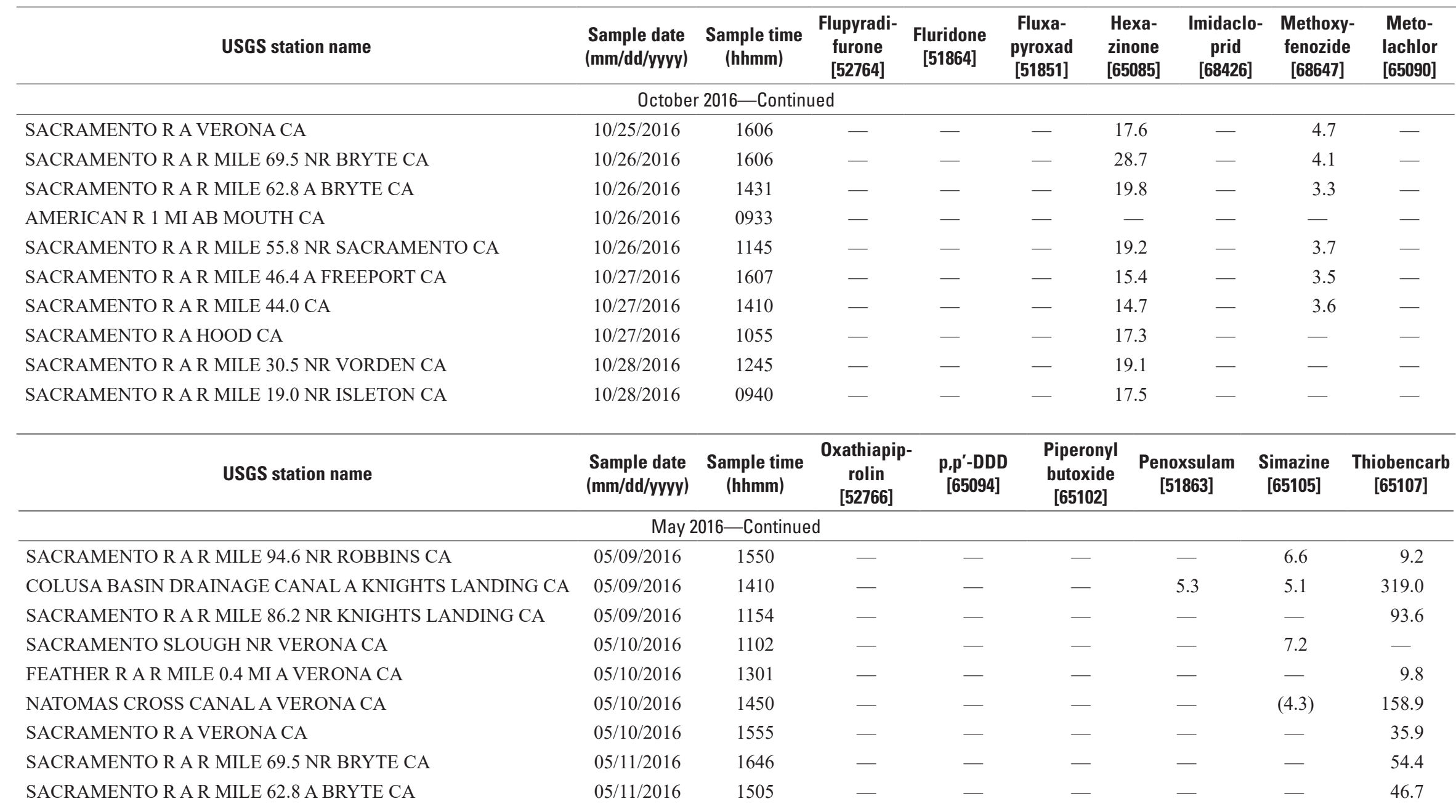


[Numbers in brackets are U.S. Geological Survey (USGS) National Water Information System (NWIS) parameter codes. Concentrations are in nanograms per liter (ng/L). Results in parentheses ( ) are below method detection limits and are estimates. The following compounds were analyzed but were not detected in any samples: 3,5-dichloroaniline, acetamiprid, acibenzolar-methyl, alachlor, allethrin, atrazine, azinphos methyl, azinphos methyl oxon, benfluralin, bifenthrin, bromuconazole, butralin, butylate, captan, carbaryl, carbofuran, carboxin, chlorothalonil, chlorpyrifos, chlorpyrifos oxon, clothianidin,

coumaphos, cyantraniliprole, cyazofamid, cycloate, cyfluthrin, cyhalofop-butyl, cyhalothrin, cymoxanil, cypermethrin, cyproconazole, cyprodinil, DCPA, deltamethrin, desthioprothioconazole, diazinon, diazinon oxon, difenconazole, dimethomorph, dinotefuran, EPTC, esfenvalerate, ethaboxam, ethalfluralin, etofenprox, famoxadone, fenamidone, fenarimol, fenbuconazole, fenhexamide, fenpropathrin, fenpyroximate, fenthion, fipronil desulfinyl amide, flonicamid, fluazinam, fludioxinil, flufenacet, flumetralin, fluopicolide, fluopyram, fluoxastrobin, flusilazole, flutolanil, flutriafol, imazalil, indoxacarb, ipconazole, iprodione, kresoxim-methyl, malathion, malathion oxon, mandipropamid, metalaxyl, metconazole, methidathion, methoprene, methyl parathion, molinate, myclobutanil, napropamide, novaluron, oryzalin, oxydiazon, oxyfluorfen, p,p'-DDE, p,p'-DDT, paclobutrazol, pentachloroaniline, pentachloroanisole, pebulate, pendimethalin, penthiopyrad, permethrin, phenothrin, phosmet, picoxystrobin, prodiamine, prometon, prometryn, propanil, propargite, propiconazole, propyzamide, pyraclostrobin, pyridaben, pyrimethanil, quinoxyfen, resmethrin, sedaxane, sulfoxaflor, tau-fluvalinate, tebuconazole, tebufenozide, tebupirimfos, tebupirimfos oxon, tefluthrin, tetraconazole, tetradifon, tetramethrin, thiabendazole, thiacloprid, thiamethoxam, thiazopyr, tolfenpyrad, triadimefon, triadimenol, triallate, tribufos, tricyclazole, trifloxystrobin, triflumizole, trifluralin, triticonazole, and zoxamide. Abbreviations: hhmm, hours:minutes; mm/dd/yyyy, month/day/year; -, not detected]

\begin{tabular}{|c|c|c|c|c|c|c|c|c|}
\hline USGS station name & $\begin{array}{l}\text { Sample date } \\
\text { (mm/dd/yyyy) }\end{array}$ & $\begin{array}{l}\text { Sample time } \\
\text { (hhmm) }\end{array}$ & $\begin{array}{c}\text { Oxathiapip- } \\
\text { rolin } \\
{[52766]}\end{array}$ & $\begin{array}{c}\text { p,p'-DDD } \\
\text { [65094] }\end{array}$ & $\begin{array}{c}\text { Piperonyl } \\
\text { butoxide } \\
\text { [65102] }\end{array}$ & $\begin{array}{c}\text { Penoxsulam } \\
{[51863]}\end{array}$ & $\begin{array}{c}\text { Simazine } \\
\text { [65105] }\end{array}$ & $\begin{array}{c}\text { Thiobencarb } \\
\text { [65107] }\end{array}$ \\
\hline \multicolumn{9}{|c|}{ May 2016-Continued } \\
\hline AMERICAN R 1 MI AB MOUTH CA & $05 / 11 / 2016$ & 0940 & - & - & - & - & - & - \\
\hline SACRAMENTO R A R MILE 55.8 NR SACRAMENTO CA & $05 / 11 / 2016$ & 1155 & - & - & - & - & - & 31.8 \\
\hline SACRAMENTO R A R MILE 46.4 A FREEPORT CA & $05 / 12 / 2016$ & 1416 & - & - & - & - & - & 33.7 \\
\hline SACRAMENTO R A R MILE 44.0 CA & $05 / 12 / 2016$ & 1212 & - & - & 5.0 & - & - & 34.6 \\
\hline SACRAMENTO R A HOOD CA & $05 / 12 / 2016$ & 0910 & - & - & 6.7 & - & - & 28.8 \\
\hline SACRAMENTO R A R MILE 30.5 NR VORDEN CA & $05 / 13 / 2016$ & 1158 & - & - & - & - & - & 34.3 \\
\hline SACRAMENTO R A R MILE 19.0 NR ISLETON CA & $05 / 13 / 2016$ & 0900 & - & - & - & - & - & 31.0 \\
\hline \multicolumn{9}{|c|}{ October 2016-Continued } \\
\hline SACRAMENTO R A R MILE 94.6 NR ROBBINS CA & $10 / 24 / 2016$ & 1132 & - & - & - & - & - & - \\
\hline COLUSA BASIN DRAINAGE CANAL A KNIGHTS LANDING CA & $10 / 24 / 2016$ & 1400 & - & - & - & - & - & - \\
\hline SACRAMENTO R A R MILE 86.2 NR KNIGHTS LANDING CA & $10 / 24 / 2016$ & 1525 & - & - & - & - & - & - \\
\hline SACRAMENTO SLOUGH NR VERONA CA & $10 / 25 / 2016$ & 1311 & - & - & - & 4.8 & - & - \\
\hline FEATHER R A R MILE 0.4 MI A VERONA CA & $10 / 25 / 2016$ & 1140 & - & - & - & - & - & - \\
\hline NATOMAS CROSS CANAL A VERONA CA & $10 / 25 / 2016$ & 1504 & 27.0 & 4.5 & - & 5.8 & - & - \\
\hline SACRAMENTO R A VERONA CA & $10 / 25 / 2016$ & 1606 & - & - & - & - & - & - \\
\hline SACRAMENTO R A R MILE 69.5 NR BRYTE CA & $10 / 26 / 2016$ & 1606 & - & - & - & - & - & - \\
\hline SACRAMENTO R A R MILE 62.8 A BRYTE CA & $10 / 26 / 2016$ & 1431 & - & - & - & - & - & - \\
\hline AMERICAN R 1 MI AB MOUTH CA & $10 / 26 / 2016$ & 0933 & - & - & - & - & - & - \\
\hline SACRAMENTO R A R MILE 55.8 NR SACRAMENTO CA & $10 / 26 / 2016$ & 1145 & - & - & - & - & - & - \\
\hline SACRAMENTO R A R MILE 46.4 A FREEPORT CA & $10 / 27 / 2016$ & 1607 & - & - & - & - & - & - \\
\hline SACRAMENTO R A R MILE 44.0 CA & $10 / 27 / 2016$ & 1410 & - & - & - & - & - & - \\
\hline SACRAMENTO R A HOOD CA & $10 / 27 / 2016$ & 1055 & - & - & - & - & - & - \\
\hline SACRAMENTO R A R MILE 30.5 NR VORDEN CA & $10 / 28 / 2016$ & 1245 & - & - & - & - & - & - \\
\hline SACRAMENTO R A R MILE 19.0 NR ISLETON CA & $10 / 28 / 2016$ & 0940 & - & - & - & - & - & - \\
\hline
\end{tabular}


Table 5. Detection frequencies and maximum concentrations for selected pesticides in surface-water samples collected at sites in the Sacramento River watershed, California, May and October 2016.

[Detection frequencies and highest measured concentrations of pesticides from 16 water-sampling sites in May and October 2016. Overall detection frequency combines both sampling events. Results in parentheses ( ) are below method detection limits and are estimates.

Abbreviations: EPA OPP, U.S. Environmental Protection Agency Office of Pesticide Programs; ng/l, nanograms per liter; $\mu \mathrm{g} / 1$, microgram per liter; -, not detected]

\begin{tabular}{|c|c|c|c|c|c|}
\hline Compound & $\begin{array}{l}\text { May } 2016 \\
\text { detection } \\
\text { frequency } \\
\text { (in percent) }\end{array}$ & $\begin{array}{c}\text { May } 2016 \\
\text { highest } \\
\text { concentration detected } \\
\text { (ng/l) }\end{array}$ & $\begin{array}{l}\text { October } 2016 \\
\text { detection } \\
\text { frequency } \\
\text { (in percent) }\end{array}$ & $\begin{array}{c}\text { October } 2016 \\
\text { highest } \\
\text { concentration detected } \\
\text { (ng/l) }\end{array}$ & $\begin{array}{c}\text { Overall } 2016 \\
\text { detection } \\
\text { frequency } \\
\text { (in percent) }\end{array}$ \\
\hline 3,4-dichloroaniline & 19 & 19.1 & 75 & 24.0 & 47 \\
\hline Azoxystrobin & 94 & 140.0 & 75 & 66.2 & 84 \\
\hline Boscalid & 94 & 29.5 & 0 & - & 47 \\
\hline Carbendazim & 6 & 8.6 & 25 & 14.2 & 16 \\
\hline Chlorantraniliprole & 25 & 8.9 & 19 & 5.4 & 22 \\
\hline Clomazone & 94 & 576.3 & 0 & - & 47 \\
\hline DCPMU & 19 & 7.4 & 50 & 48.8 & 34 \\
\hline DCPU & 13 & $(3.2)$ & 19 & 9.3 & 16 \\
\hline Dithiopyr & 0 & - & 6 & 26.2 & 3 \\
\hline Diuron & 94 & 26.4 & 75 & 326.0 & 84 \\
\hline Fipronil & 0 & - & 6 & 3.6 & 3 \\
\hline Fipronil desulfinyl & 0 & - & 6 & 8.8 & 3 \\
\hline Fipronil sulfide & 0 & - & 6 & 3.0 & 3 \\
\hline Fipronil sulfone & 0 & - & 6 & 8.8 & 3 \\
\hline Flupyradifurone & 0 & - & 6 & 4.7 & 3 \\
\hline Fluridone & 0 & - & 6 & (3.4) & 3 \\
\hline Fluxapyroxad & 6 & 13.6 & 0 & - & 3 \\
\hline Hexazinone & 94 & 29.1 & 81 & 33.7 & 88 \\
\hline Imidacloprid & 19 & (3.4) & 6 & 6.1 & 13 \\
\hline Methoxyfenozide & 25 & 8.0 & 63 & 52.0 & 44 \\
\hline Metolachlor & 81 & 78.3 & 0 & - & 41 \\
\hline Oxathiapiprolin & 0 & - & 6 & 27.0 & 3 \\
\hline p,p'-DDD & 0 & - & 6 & 4.5 & 3 \\
\hline Piperonyl butoxide & 13 & 6.7 & 0 & - & 6 \\
\hline Penoxsulam & 6 & 5.3 & 13 & 5.8 & 9 \\
\hline Simazine & 25 & 7.2 & 0 & - & 13 \\
\hline Thiobencarb & 88 & 319.0 & 0 & - & 44 \\
\hline
\end{tabular}


Table 6. Pesticide concentrations in suspended sediment filtered from surface-water samples collected at sites in the Sacramento River watershed, California, May and October 2016.

[Numbers in brackets are U.S. Geological Survey (USGS) National Water Information System (NWIS) parameter codes. The following compounds were analyzed but were not detected in any samples: 3,4-dichloroaniline, 3,5-dichloroaniline, acibenzolar-methyl, alachlor, allethrin, atrazine, azinphos methyl, azinphos methyl oxon, azoxystrobin, benfluralin, bifenthrin, boscalid, bromuconazole, butralin, butylate, captan, carbaryl, carbofuran, chlorothalonil, chlorpyrifos, chlorpyrifos oxon, coumaphos, cycloate, cyfluthrin, cyhalofop-butyl, cyhalothrin, cypermethrin, cyproconazole, cyprodinil, DCPA, deltamethrin, diazinon, diazinon oxon, difenconazole, dimethomorph, dithiopyr, EPTC, esfenvalerate, ethalfluralin, etofenprox, famoxadone, fenamidone, fenarimol, fenbuconazole, fenhexamide, fenpropathrin, fenpyroximate, fenthion, fipronil, fipronil desulfinyl amide, fipronil desulfinyl, fiprinil sulfide, fiprinil sulfone, fluazinam, fludioxinil, flufenacet, flumetralin, fluopicolide, fluopyram, fluoxastrobin, flusilazole, flutolanil, flutriafol, fluxapyroxad, hexazinone, imazalil, indoxacarb, ipconazole, iprodione, kresoxim-methyl, malathion, malathion oxon, metalaxyl, metconazole, methidathion, methoprene, methyl parathion, metolachlor, molinate, myclobutanil, napropamide, novaluron, oxydiazon, oxyfluorfen, p,p'-DDD, p,p'-DDE, p,p'-DDT, paclobutrazol, pentachloroanisole, pentachloronitrobenzene, pebulate, pendimethalin, permethrin, phenothrin, phosmet, picoxystrobin, piperonyl butoxide, prodiamine, prometon, prometryn, propanil, propargite, propiconazole, propyzamide, pyraclostrobin, pyridaben, pyrimethanil, quinoxyfen, resmethrin, sedaxane, simazine, tau-fluvalinate, tebuconazole, tebupirimfos, tebupirimfos oxon, tefluthrin, tetraconazole, tetradifon, tetramethrin, thiazopyr, triadimefon, triadimenol, triallate, tribufos, trifloxystrobin, triflumizole, trifluralin, triticonazole, and zoxamide. Abbreviations: hhmm, hours:minutes; mm/dd/yyyy, month/day/year; ng/L, nanogram per liter; - , not detected]

\begin{tabular}{lcccccc}
\hline \multicolumn{1}{c}{ USGS station name } & $\begin{array}{c}\text { USGS station } \\
\text { number }\end{array}$ & $\begin{array}{c}\text { Sample date } \\
(\mathbf{m m} / \mathbf{d d} / \mathbf{y y y})\end{array}$ & $\begin{array}{c}\text { Sample time } \\
\text { (hhmm) }\end{array}$ & $\begin{array}{c}\text { Sediment } \\
\text { weight } \\
\text { (gram) }\end{array}$ & $\begin{array}{c}\text { Clomazone } \\
\text { [67562] } \\
\text { (ng/L) }\end{array}$ & $\begin{array}{c}\text { Thiobencarb } \\
\text { [65107] } \\
\text { (ng/L) }\end{array}$ \\
\hline $\begin{array}{l}\text { COLUSA BASIN DRAINAGE CANAL A } \\
\text { KNIGHTS LANDING CA }\end{array}$ & 384804121432401 & $05 / 09 / 2016$ & 1410 & 0.067 & 5.4 & 5.4 \\
$\begin{array}{l}\text { SACRAMENTO SLOUGH NR VERONA CA } \\
\text { NATOMAS CROSS CANAL A VERONA CA }\end{array}$ & 384649121381101 & $05 / 10 / 2016$ & 1102 & 0.036 & 7.1 & - \\
\hline
\end{tabular}

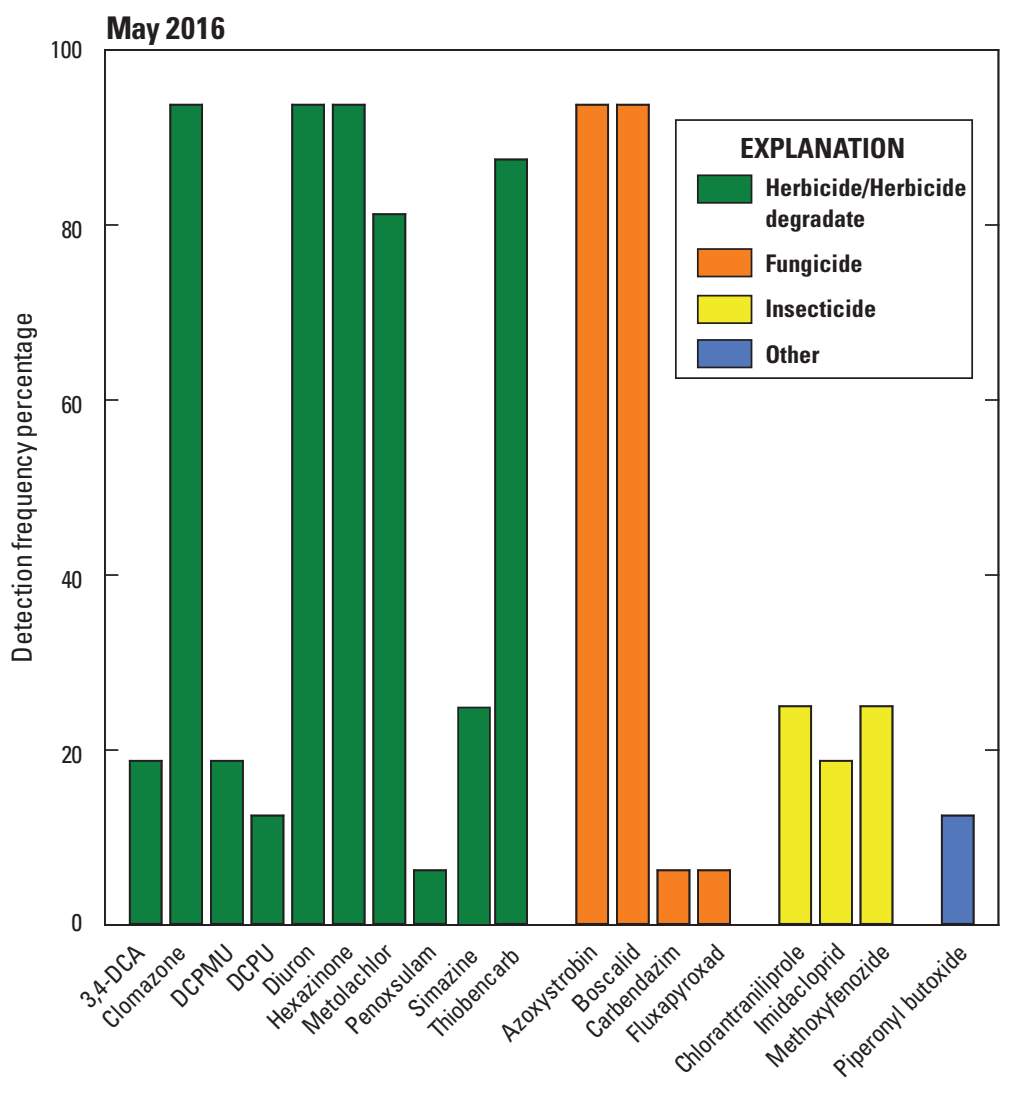

Figure 3. Pesticide detection frequencies in 16 samples from sites in the Sacramento River watershed, California, during May 2016. 
During the October sampling event, the herbicides hexazinone (81 percent detection frequency), diuron ( 75 percent), and the herbicide degradates N-3,4-dichlorophenyl-N-methyl-urea (DCPMU; 50 percent); and 3,4-dichloroaniline (3,4-DCA; 75 percent); along with the fungicide azoxystrobin (75 percent); and the insecticide methoxyfenozide (63 percent), were the most frequently detected pesticides in water samples (fig. 5; table 5). Pesticide concentrations ranged from below the MDLs to $326 \mathrm{ng} / \mathrm{L}$ (diuron), and maximum concentrations were all below
$70 \mathrm{ng} / \mathrm{L}$, except for one detection of diuron (fig. 6; table 5). Average pesticide concentrations and the average number of pesticide detections at the agricultural drainage indicator sites were over 80 percent greater than in the Sacramento River integrator sites. All pesticides were detected at concentration levels lower than the U.S. Environmental Protection Agency's aquatic life benchmarks (U.S. Environmental Protection Agency, 2017). No pesticides were detected in the suspended sediments filtered from the water samples collected during the October sampling event.

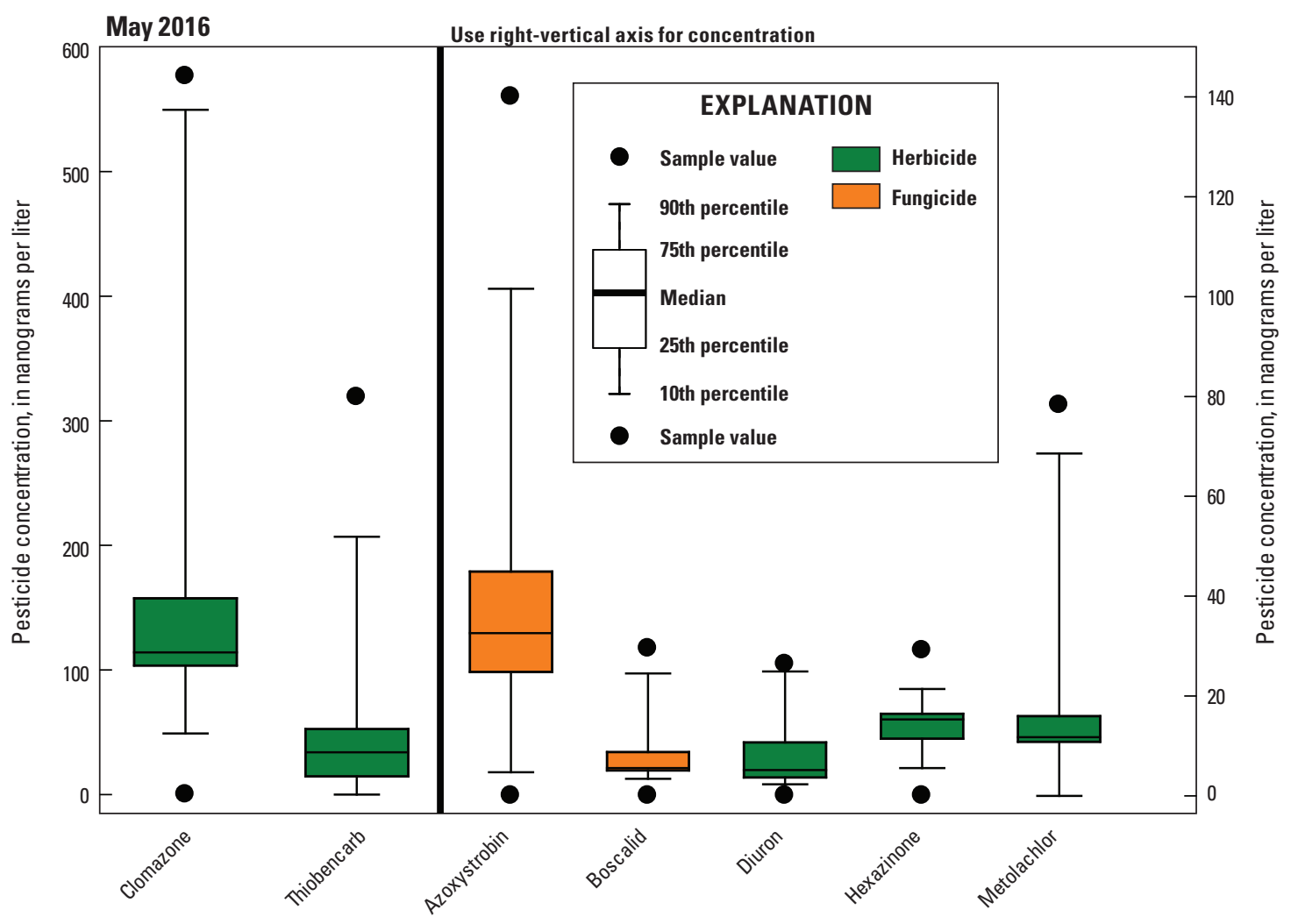

Figure 4. Frequency distribution of concentrations of the most frequently detected pesticides at sites in the Sacramento River watershed, California, during May 2016. 


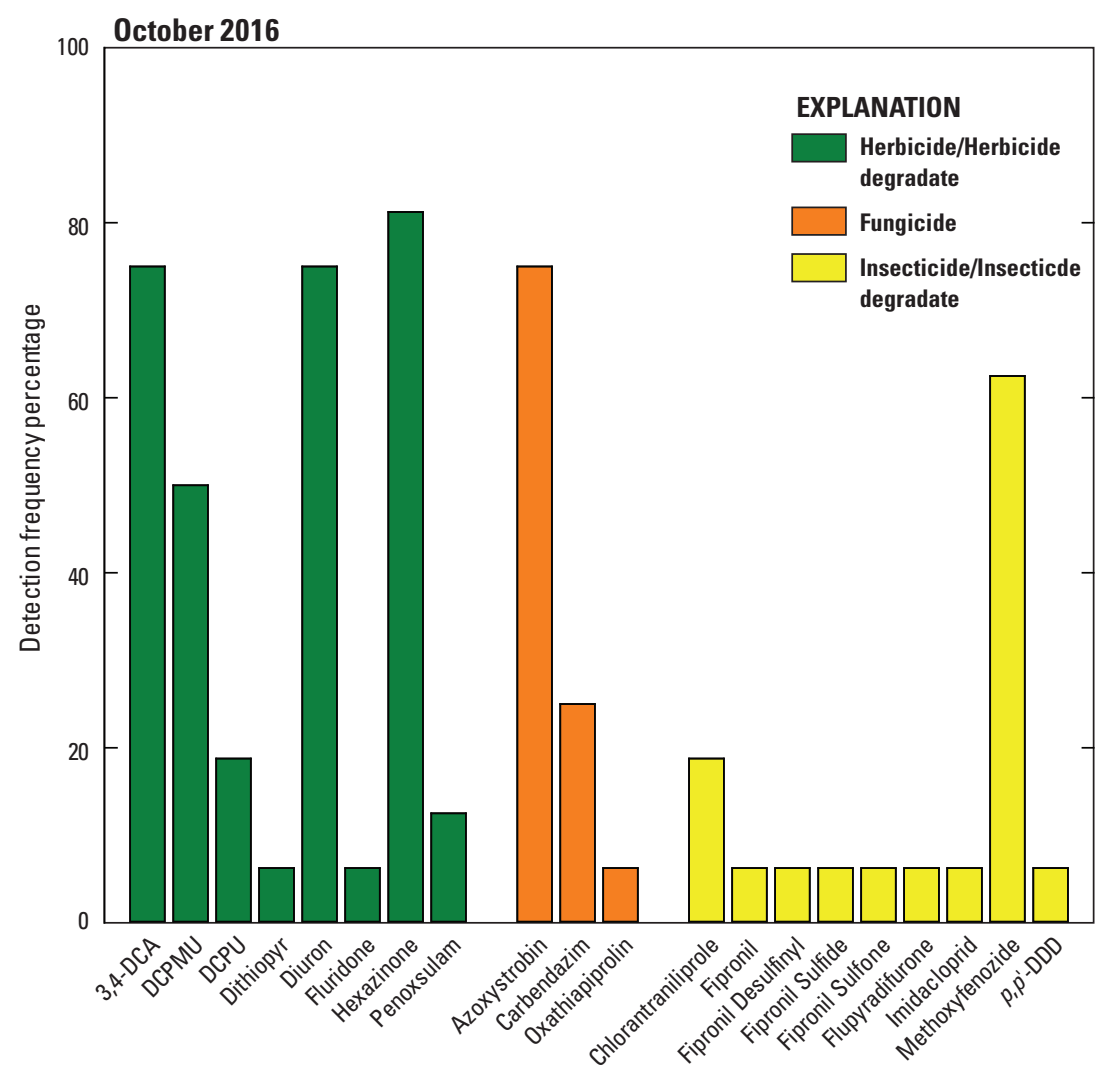

Figure 5. Pesticide detection frequencies in 16 samples from sites in the Sacramento River watershed, California, during 0 ctober 2016.

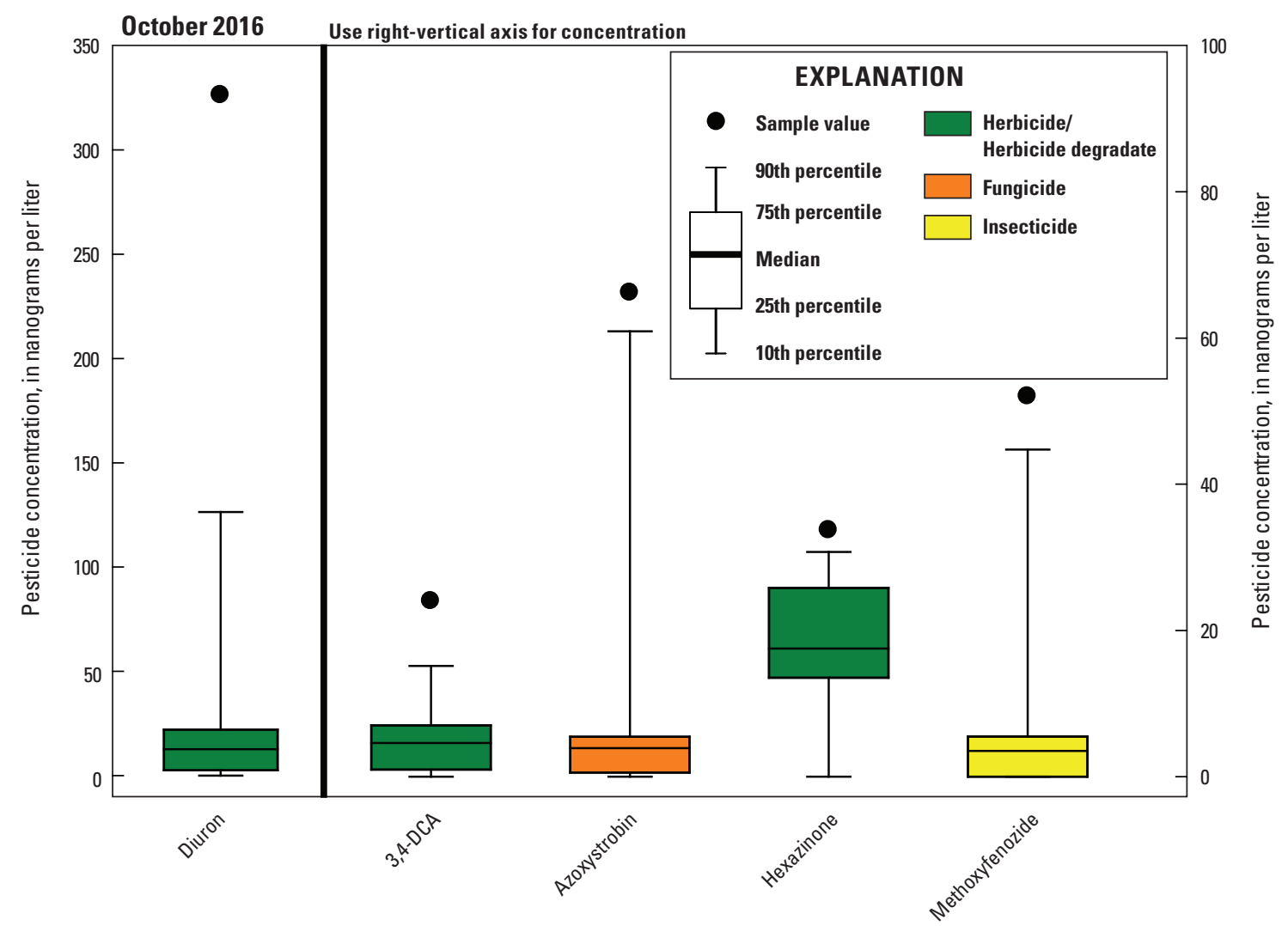

Figure 6. Frequency distribution of concentrations of the most frequently detected pesticides at sites in the Sacramento River watershed, California, during October 2016. 


\section{References Cited}

California Department of Water Resources, 1993, Sacramento-San Joaquin Delta atlas - California: Department of Water Resources, $121 \mathrm{p}$.

California Department of Water Resources, 1994, California water plan update: California Department of Water Resources Bulletin 160-93, v. 1, 397 p.

California State Water Resources Control Board, 2014, Collections of water and bed sediment samples with associated field measurements and physical habitat in California: California State Water Resources Control Board Standard Operating Procedure no. 1.1, 62 p., accessed June 14, 2017, at https://www.waterboards.ca.gov/water_ issues/programs/swamp/docs/final_collect_water_sed_ phys_habitat.pdf.

Cloern, J.E., and Jassby, A.D., 2012, Drivers of change in estuarine-coastal ecosystems-Discoveries from four decades of study in San Francisco Bay: Reviews of Geophysics, v. 50, no. 4, RG4001, https://doi.org/10.1029/2012RG000397.

Dileanis, P.D., Bennett, K.P., and Domagalski, J.L., 2002, Occurrence and transport of diazinon in the Sacramento River, California, and selected tributaries during three winter storms, January-February 2000: U.S. Geological Survey Water-Resources Investigations Report 2002-4101, 71 p., https://doi.org/10.3133/wri024101.

Domagalski, J.L., Knifong, D.L., MacCoy, D.E., Dileanis, P.D., Dawson, B.J., and Majewski, M.S., 1998, Water quality assessment of the Sacramento River Basin, California-Environmental setting and study design: U.S. Geological Survey Water-Resources Investigations Report 97-4254, 31 p., https://doi.org/10.3133/wri974254.

Domagalski, J.L., and Dileanis, P.D., 2000, Water quality assessment of the Sacramento River Basin, CaliforniaWater quality of fixed sites, 1996-1998: U.S. Geological Survey Water-Resources Investigations Report 2000-4247, 60 p., https://doi.org/10.3133/wri004247.

Dugdale, R., Wilkerson, F., Parker, A.E., Marchi, A., and Taberski, K., 2012, River flow and ammonium discharge determine spring phytoplankton bloom in an urbanized estuary: Estuarine, Coastal and Shelf Science, v. 115, p. $187-199$.

Gatidou, G., and Thomaidis, N.S., 2007, Evaluation of single and joint toxic effects of two antifouling biocides, their main metabolites and copper using phytoplankton bioassays: Aquatic Toxicology, v. 85, no. 3, p 184-191, https://doi.org/10.1016/j.aquatox.2007.09.002.
Gilliom, R.J., Alley, W.M., and Gurtz, M.E., 1995, Design of the National Water-Quality Assessment programOccurrence and distribution of water-quality conditions: U.S. Geological Survey Circular 1112, 33 p., https://doi.org/10.3133/cir1112.

Hill, I.R., 1989, Aquatic organisms and pyrethroids: Pesticide Science, v. 27, p. 429-465.

Hladik, M.L., and Calhoun, D.L., 2012, Analysis of the herbicide diuron, three diuron degradates, and six neonicotinoid insecticides in water-Method details and application to two Georgia streams: U.S. Geological Survey Scientific Investigations Report 2012-5206, 10 p., https://doi.org/10.3133/sir20125206.

Hladik, M.L., and McWayne, M.M., 2012, Methods of analysis - Determination of pesticides in sediment using gas chromatography/mass spectrometry: U.S. Geological Survey Techniques and Methods 5-C3, 18 p., https://pubs.usgs.gov/tm/tm5c3/pdf/tm5-C3.pdf.

Hladik, M.L., Smalling, K.L., and Kuivila, K.M., 2008, A multi-residue method for the analysis of pesticides and pesticide degradates in water using Oasis HLB solid phase extraction and gas chromatography-ion trap mass spectrometry: Bulletin of Environmental Contamination and Toxicology, v. 80, no. 2, p. 139-144, https://doi.org/10.1007/s00128-007-9332-2.

Hladik, M.L., Smalling, K.L., and Kuivila, K.M., 2009, Methods of analysis - Determination of pyrethroid insecticides in water and sediment using gas chromatography/mass spectrometry: U.S. Geological Survey Techniques and Methods 5-C2, 18 p., https://pubs.er.usgs.gov/publication/tm5C2.

Kimmerer, W.J., Parker, A.E., Lidström, U.E., and Carpenter E.J., 2012, Short-term and interannual variability in primary production in the low-salinity zone of the San Francisco Estuary: Estuaries and Coasts, v. 35, no. 4, p. 913-929, https://doi.org/10.1007/s12237-012-9482-2.

Kratzer, C.R., Zamora, C., and Knifong, D.L., 2002, Diazinon and chlorpyrifos loads in the San Joaquin River Basin, California, January and February 2000: U.S. Geological Survey Water Resources Investigations Report 2002-4103, 38 p., https://doi.org/10.3133/wri024103.

Laskowski, D.A., 2002, Physical and chemical properties of pyrethroids: Reviews of Environmental Contamination and Toxicology, v. 174, p. 49-170.

Magnusson, M., Heimann, K., Quayle, P., and Negri, A.P., 2010, Additive toxicity of herbicide mixtures and comparative sensitivity of tropical benthic microalgae: Marine Pollution Bulletin, v. 60, no. 11, p. 1978-1987, https://doi.org/10.1016/j.marpolbul.2010.07.031. 
Orlando, J.L., and Kuivila, K.M., 2005, Concentrations of organic contaminants detected during managed flow conditions, San Joaquin River and Old River, California, 2001: U.S. Geological Survey Data Series 120, 13 p., https://doi.org/10.3133/ds120.

Orlando, J.L., McWayne, M., Sanders, C., and Hladik, M., 2013, Dissolved pesticide concentrations in the Sacramento-San Joaquin Delta and Grizzly Bay, California, 2011-12: U.S. Geological Survey Data Series 779, 24 p., https://doi.org/10.3133/ds779.

Orlando, J.L., McWayne, M., Sanders, C., and Hladik, M., 2014, Dissolved pesticide concentrations entering the Sacramento-San Joaquin Delta from the Sacramento and San Joaquin Rivers, California, 2012-13: U.S. Geological Survey Data Series 876, 28 p., https://doi.org/10.3133/ds876.

Panshin, S.Y., Dubrovsky, N.M., Gronberg, J.M, and Domagalski, J.L., 1998, Occurrence and distribution of dissolved pesticides in the San Joaquin River Basin, California: U.S. Geological Survey Water-Resources Investigations Report 98-4032, 88 p., https://doi.org/10.3133/wri984032.

Parker, A.E., Dugdale, R.C., and Wilkerson, F.P., 2012, Elevated ammonium concentrations from wastewater discharge depress primary productivity in the Sacramento River and Northern San Francisco Estuary: Marine Pollution Bulletin, v. 64, no. 3, p. 574-586, https://doi.org/10.1016/j.marpolbul.2011.12.016.

Peterson, H.G., Boutin, C., Martin, P.A., Freemark, K.E., Ruecker, N.J., and Moody, M.J., 1994, Aquatic phytotoxicity of 23 pesticides applied at expected environmental concentrations: Aquatic Toxicology, v. 28, no. 3-4, p. 275292, https://doi.org/10.1016/0166-445X(94)90038-8.

Ricart, M., Barcelo, D., Geiszinger, A., Guasch, H., Lopez de Alda, M., Romani, A.M., Vidal, G., Villagrasa, M., and Sabater, S., 2009, Effects of low concentrations of the phenylurea herbicide diuron on biofilm algae and bacteria: Chemosphere, v. 76, no. 10, p. 1392-1401, https://doi.org/10.1016/j.chemosphere.2009.06.017.
Sommer, T., and Mejia, F., 2013, A place to call home-A synthesis of Delta Smelt habitat in the Upper San Francisco Estuary: San Francisco Estuary and Watershed Science, v. 11 , no. 2,25 p.

Sommer, T., Armor, C., Baxter, R., Breuer, R., Brown, L., Chotkowski, M., Culberson, S., Feyrer, F., Gingras, M., Herbold, B., Kimmerer, W., Mueller-Solger, A., Nobriga, M., Souza, K., 2007, The collapse of pelagic fishes in the Upper San Francisco Estuary: American Fisheries Society, v. 32, no, 6, p. 270-277

U.S. Census Bureau, 2011, Census 2010: U.S. Department of Commerce, accessed May 2011 at http://www.census.gov/2010census/data/.

U.S. Environmental Protection Agency, 1992, Definition and procedure for the determination of the method detection limit, revision 1.11: Code of Federal Regulations 40, Protection of the Environment, CFR Part 136, appendix B, p. 565-567.

U.S. Environmental Protection Agency, 2017, Aquatic life benchmarks and ecological risk assessments for registered pesticides: U.S. Environmental Protection Agency Office of Pesticide Programs, accessed June 11, 2017, at https://www.epa.gov/pesticide-science-and-assessingpesticide-risks/aquatic-life-benchmarks-pesticideregistration.

U.S. Geological Survey, 2014, National Land Cover Dataset 2011: U.S. Geological Survey, accessed April 10, 2014, at http://www.mrlc.gov/.

Weston, D.P., and Lydy, M.J., 2010, Urban and agricultural sources of pyrethroid insecticides to the Sacramento-San Joaquin Delta of California: Environmental Science \& Technology, v. 44, no. 5, p. 1833-1840, https://pubs.acs.org/doi/abs/10.1021/es9035573.

Winder, M., and Jassby, A.D., 2011, Shifts in zooplankton community structure-Implications for food web processes in the Upper San Francisco Estuary: Estuaries and Coasts, v. 34 , no. 4, p. $675-690$, https://doi.org/10.1007/s12237-010-9342-x. 
Publishing support provided by the U.S. Geological Survey Science Publishing Network, Sacramento Publishing Service Center

For more information concerning the research in this report, contact the Director, California Water Science Center U.S. Geological Survey $6000 \mathrm{~J}$ Street, Placer Hall Sacramento, California 95819 https://ca.water.usgs.gov 


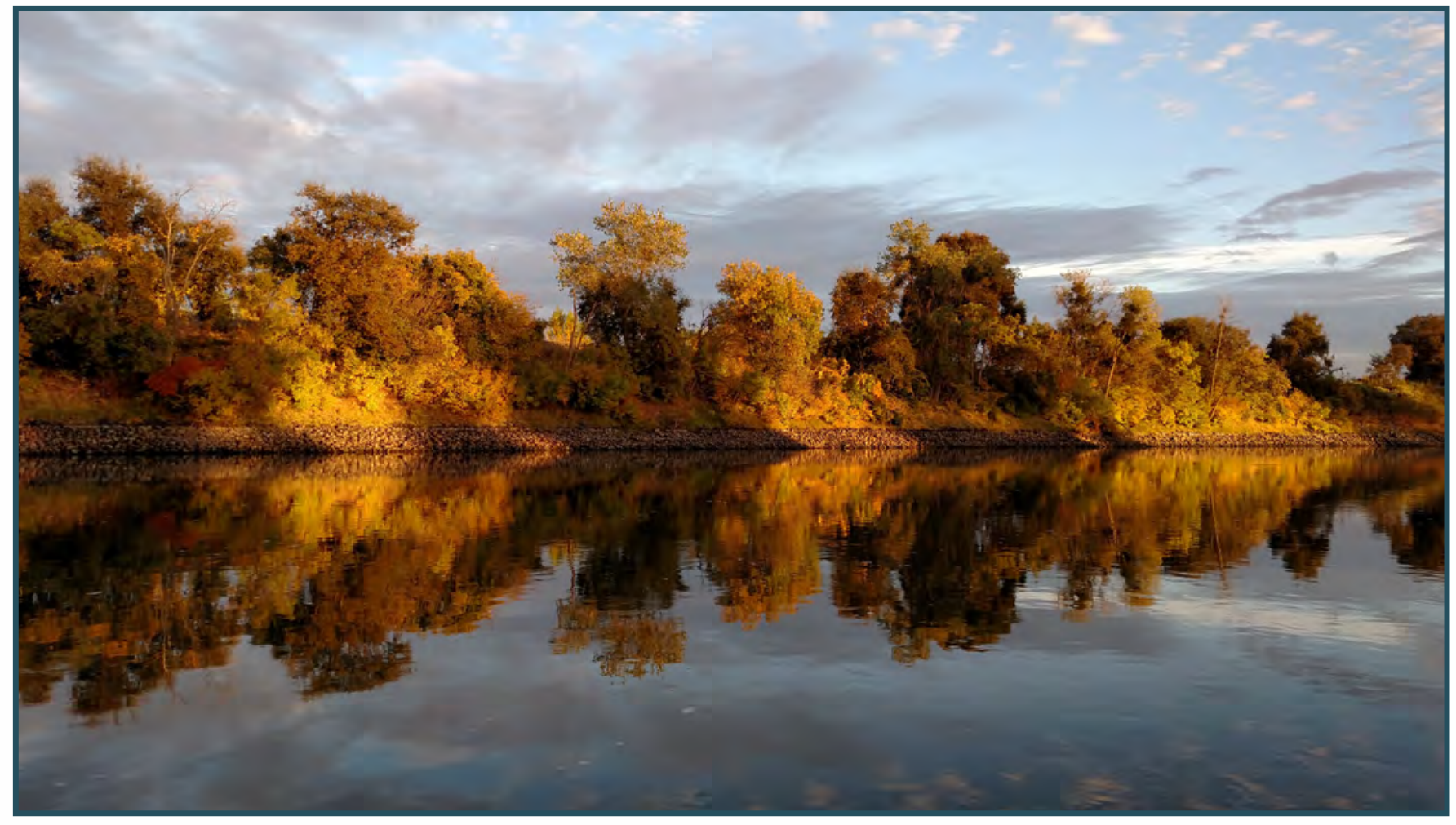

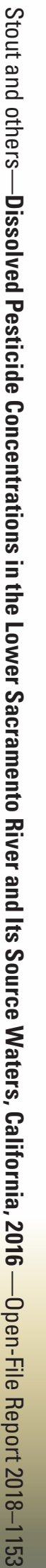

